\title{
Microbe-Mediated Biosynthesis of Nanoparticles: Applications and Future Prospects
}

\author{
Bhupendra Koul ${ }^{1, *,+}\left(\mathbb{D}\right.$, Anil Kumar Poonia ${ }^{2,+}$, Dhananjay Yadav ${ }^{3, *}$ (D) and Jun-O Jin ${ }^{3,4, *}$ \\ 1 School of Bioengineering and Biosciences, Lovely Professional University, Phagwara 144411, Punjab, India \\ 2 Centre for Plant Biotechnology, CCSHAU, Hisar 125004, Haryana, India; anil_poonia2005@yahoo.com \\ 3 Department of Medical Biotechnology, Yeungnam University, Gyeongsan 38541, Korea \\ 4 Research Institute of Cell Culture, Yeungnam University, Gyeongsan 38541, Korea \\ * Correspondence: bhupendra.18673@lpu.co.in (B.K.); dhanyadav16481@gmail.com (D.Y.); \\ jinjo@yu.ac.kr (J.-O.J.) \\ + These authors contributed equally to this work.
}

check for updates

Citation: Koul, B.; Poonia, A.K.; Yadav, D.; Jin, J.-O Microbe-Mediated Biosynthesis of Nanoparticles: Applications and Future Prospects. Biomolecules 2021, 11, 886.

https://doi.org/10.3390/biom11060886

Received: 24 April 2021

Accepted: 9 June 2021

Published: 15 June 2021

Publisher's Note: MDPI stays neutral with regard to jurisdictional claims in published maps and institutional affiliations.

Copyright: (c) 2021 by the authors. Licensee MDPI, Basel, Switzerland. This article is an open access article distributed under the terms and conditions of the Creative Commons Attribution (CC BY) license (https:// creativecommons.org/licenses/by/ $4.0 /)$.

\begin{abstract}
Nanotechnology is the science of nano-sized particles/structures ( 100 nm) having a high surface-to-volume ratio that can modulate the physical, chemical and biological properties of the chemical compositions. In last few decades, nanoscience has attracted the attention of the scientific community worldwide due to its potential uses in the pharmacy, medical diagnostics and disease treatment, energy, electronics, agriculture, chemical and space industries. The properties of nanoparticles (NPs) are size and shape dependent. These characteristic features of nanoparticles can be explored for various other applications such as computer transistors, chemical sensors, electrometers, memory schemes, reusable catalysts, biosensing, antimicrobial activity, nanocomposites, medical imaging, tumor detection and drug delivery. Therefore, synthesizing nanoparticles of desired size, structure, monodispersity and morphology is crucial for the aforementioned applications. Recent advancements in nanotechnology aim at the synthesis of nanoparticles/materials using reliable, innoxious and novel ecofriendly techniques. In contrast to the traditional methods, the biosynthesis of nanoparticles of a desired nature and structure using the microbial machinery is not only quicker and safer but more environmentally friendly. Various microbes, including bacteria, actinobacteria, fungi, yeast, microalgae and viruses, have recently been explored for the synthesis of metal, metal oxide and other important NPs through intracellular and extracellular processes. Some bacteria and microalgae possess specific potential to fabricate distinctive nanomaterials such as exopolysaccharides, nanocellulose, nanoplates and nanowires. Moreover, their ability to synthesize nanoparticles can be enhanced using genetic engineering approaches. Thus, the use of microorganisms for synthesis of nanoparticles is unique and has a promising future. The present review provides explicit information on different strategies for the synthesis of nanoparticles using microbial cells; their applications in bioremediation, agriculture, medicine and diagnostics; and their future prospects.
\end{abstract}

Keywords: nanotechnology; nanoparticle; microbes; ecofriendly; nanomaterials bioremediation

\section{Introduction}

Nanotechnology is an emerging branch of science which deals to with excising the structure of matter between 1 and 100 nanometers on the atomic, molecular and supramolecular level for the development of desired properties and functions and for diverse applications. In the last few decades, nanoscience has attracted the attention of the scientific community worldwide for the sustainable production of various nanoparticles (NPs), using innovative techniques, which finds applications in the pharmacy, medical diagnostics and disease treatment, energy, electronics, agriculture, chemical and space industries [1-5]. The novel applications of metal NPsin diverse industrial domains have also attracted the interest of researchers towards the synthesis and production of important metal NPs using simpler and efficient techniques [1,2,5]. It is expected that by 2030 , the global nanomaterials 
market will grow by $20 \%$ [6]. The synthesis of NPs of a desired size, structure, monodispersity and morphology is crucial in terms of their various applications in nanoscience and associated nanobusiness [7].

A recent advancement in nanotechnology is based on the synthesis of NPs/materials using novel techniques. NPs can be fabricated using physical, chemical and biological methods (Figure 1). The major physical methods used for the synthesis of nanoparticles include pyrolysis, physical vapor deposition (PVD), lithography, crushing, grinding, milling and ball processing. On the other hand, chemosynthesis of nanoparticles consists of sol gel synthesis, chemical reduction, electrolysis, CVD (chemical vapor deposition), photocatalytic reduction and microwave-assisted synthesis.

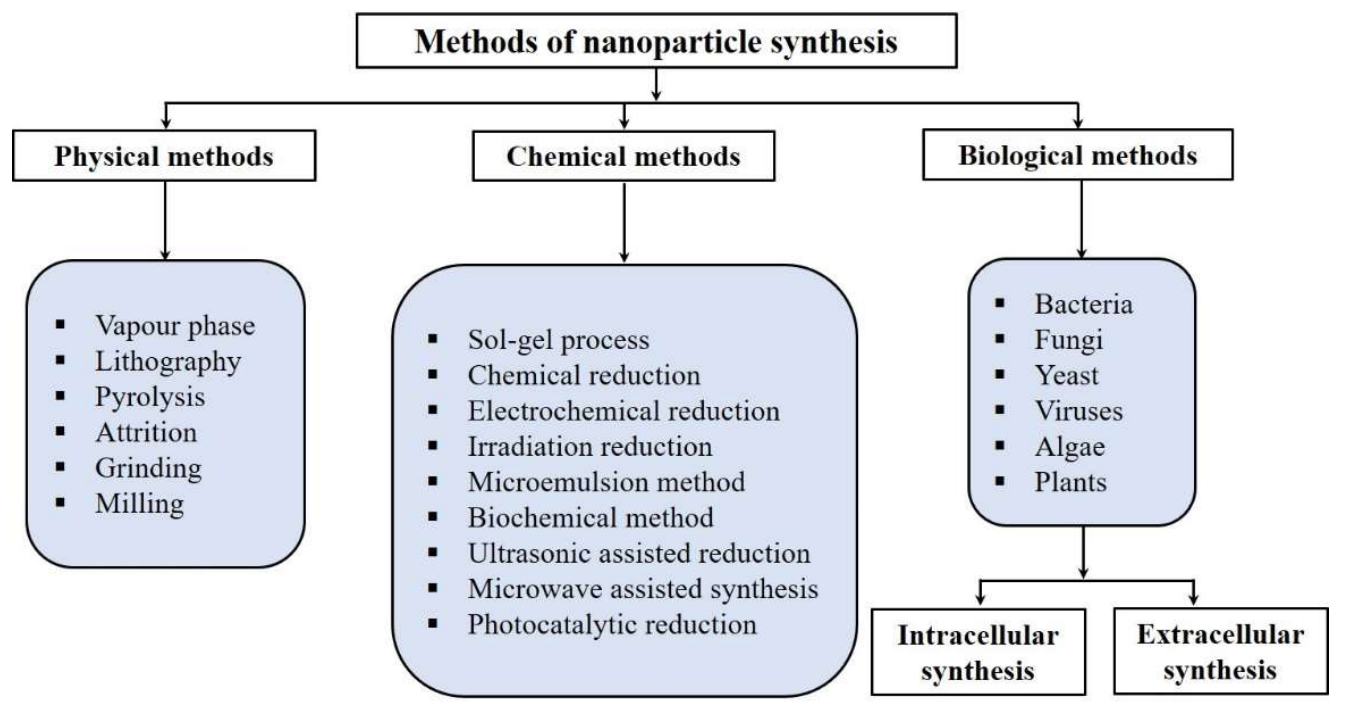

Figure 1. Different methods of NPs synthesis.

The physical methods are inferior for the large-scale production of nanomaterials because of the lower yield of NPs, higher energy needs and higher input cost [8]. The chemical methods of NPs synthesis have been the methods of choice over the past few years due to the consumption of less energy during the reduction of metals and production of homogenous NPs with high accuracy [9]. Thus, these traditional methods of NPs synthesis are laborious, time consuming, hazardous and based on the use of toxic chemicals, which are unsafe (cytotoxic, genotoxic, carcinogenic) and act as potent environmental pollutants [10-12]. Moreover, the biomedical applications of NPs produced from chemosynthesis have been limited due to their instability and toxic nature $[13,14]$.

Therefore, it is necessary to develop efficient, reliable, innoxious and ecofriendly techniques for the synthesis of NPs. This can be achieved by synthesizing NPs using natural sources, such as the biological system, microorganisms and their enzymes and biodegradable polymers.

NP synthesis using biological systems is rapid, feasible and ecofriendly. Moreover, the toxicity and size characteristics of the NPs can be controlled. Synthesis of NPs using bacteria, actinobacteria, fungi, yeast, microalgae and viruses has been explored by many researchers for the production of desired NPs [2,15-21]. Microbial cells have the natural ability to grow in diverse habitats and are fast growing and easy to maintain. Bacteria and microalgae possess the specific potential to fabricate distinctive nanomaterials, such as exopolysaccharides, nanocellulose and nanowires [22-24]. A schematic representation of microbe-based biological synthesis of different nanoparticles, its characterization and its applications is discussed in Figure 2. 


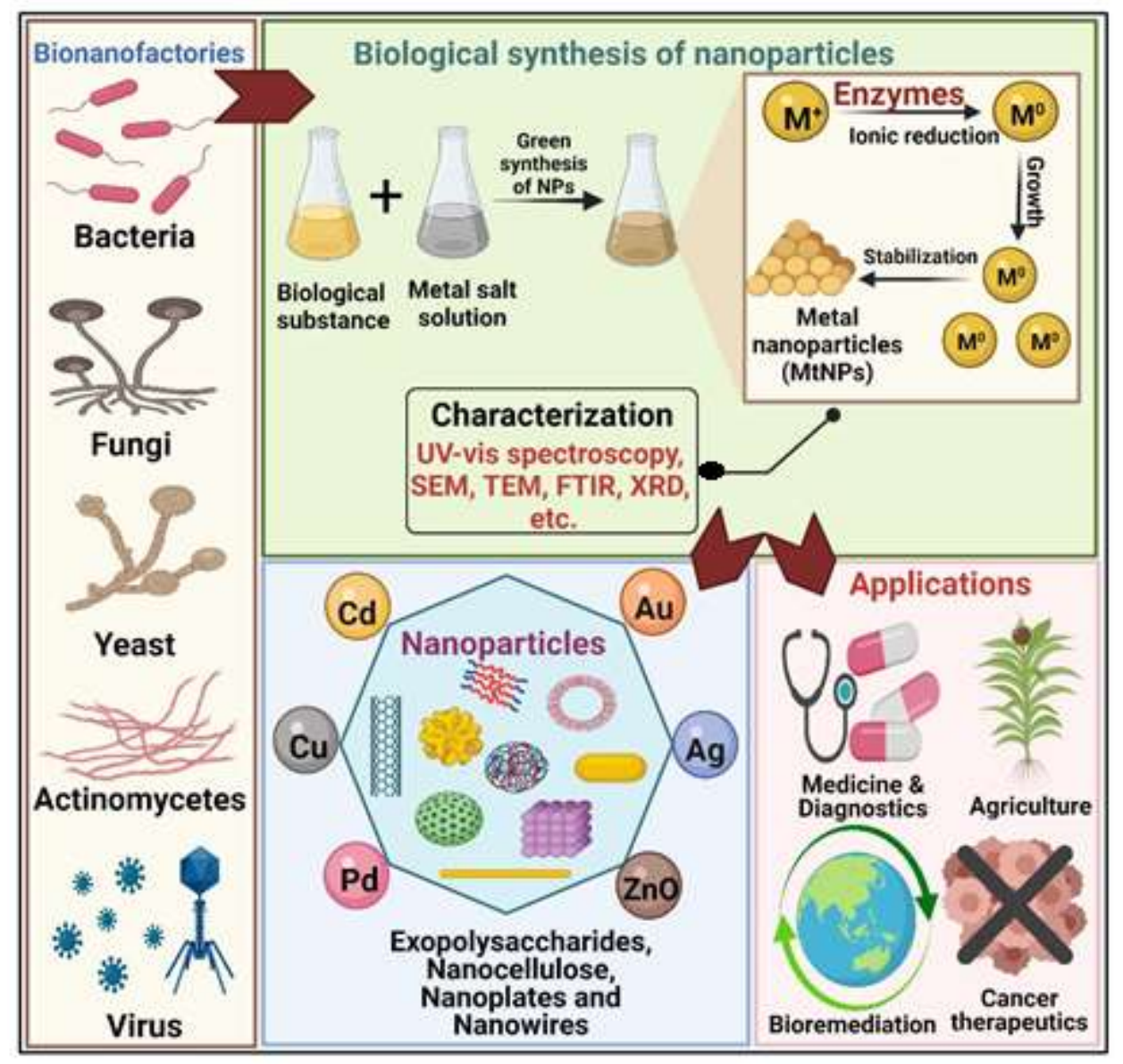

Figure 2. Depicts a schematic representation of the microbe-based biological synthesis of various nanoparticles, their characterization and applications.

Bacterial species like Bacillus licheniformis, Pseudomonas deceptionensis, Pyrococcusfuriosus, Pyrobaculum islandicum, Pseudomonas aeruginosa, etc., have been recently explored for the synthesis of silver $(\mathrm{Ag})$, gold $(\mathrm{Au})$, iron $(\mathrm{Fe})$, nickel $(\mathrm{Ni})$, zinc $(\mathrm{Zn})$ and other important NPs $[2,16-19,21,25]$. It is interesting to note that the metabolic pathway of microbial machinery can also be altered through genetic engineering for the fabrication of NPs with specific physical, chemical and biological properties [26]. The application of microorganisms for the synthesis of NPs is unique but also has scope for improvement. The recent outbreak of COVID-19 has introduced a huge challenge to the field of medicine. Nanotechnology has the immense potential to strategically find solutions and to cope with such pandemic situations, as the NPs can be deployed for diagnosis and treatment of the COVID-19 disease [27]. Hence, the present review is focused on different strategies of the microbe-mediated synthesis of NPs; the applications of these NPs in bioremediation, pharmaceuticals, agriculture, medicine and diagnostics; and future prospects.

\section{Strategies for Synthesis of Nanoparticles Using Microbes}

The fabrication of NPs from living sources (bacteria, actinobacteria, yeast, fungi, algae and viruses) is quite safer than that of chemical and physical methods [2,15-21]. The fabrication of NPs using bacteria is preferred over other microbes as they can be cultured feasibly in artificial conditions with an ambient growth rate. Microbes can adapt in higher concentrations of metals and have the potential to reduce inorganic materials into NPs through their extracellular or intracellular routes [2,15]. Microbes absorb metal ions from their surrounding environment/media and convert these metallic ions into elemental form via an enzymatic reduction [28]. 
In the extracellular fabrication of NPs, microbes are grown in suitable media. The broth containing microbial cells is centrifuged, and the supernatant containing microbial enzymes is then used for the synthesis of NPs [29-31]. The supernatant containing reductase enzymes is allowed to react with the metal ions in a separate vessel. The bioreduction of metal ions in a cell-free supernatant results in the formation of NPs [32]. The characteristics of newly synthesized NPs (morphology, uniformity and interaction) are then determined by XRD (X-ray diffraction), SEM (scanning electron microscopy), TEM (transmission electron microscopy) and FTIR (Fourier transform infrared spectroscopy) (Figure 2) [33].

In the intracellular fabrication of NPs, the cellular mechanism of microbial cells is used for the synthesis of NPs. The microbial cultures are maintained in appropriate liquid media and the microbial biomass is washed with sterile distilled water followed by centrifugation to obtain the biomass pellet [14,16,34]. The microbial biomass is then allowed to react with an aqueous solution of metals. The solution containing the microbial biomass and metals is then cultivated at desired incubation conditions till a specific chromatic change is observed. The appearance of a specific color shows the formation of NPs. When a whitish yellow to yellow color appears, it suggests the synthesis of zinc and manganese NPs. While the appearance of a pale yellow to pinkish color suggests the synthesis of gold NPs, and a pale yellow to brownish color suggests the synthesis of AgNPs [35]. In this process, the metal ions (positively charged) are trapped within the cell wall (negatively charged) of microbial cells. The bioreduction of these metal ions within the cell wall by enzymes results in the formation of nanoclusters, and finally the NPs diffuse from the cell wall to the solution [32]. Hence, during the intracellular process the metal ions are absorbed by the microbial cells, and in the presence of cellular enzymes, metal ions are transformed into NPs within the cells, while, in the extracellular process, the metal ions are trapped outside the cell surface where they are reduced by cellular enzymes to form NPs [36].

\subsection{Bacterial-Mediated Biosynthesis of Nanoparticles}

Various metal NPs, such as $\mathrm{Ag}, \mathrm{Au}, \mathrm{Cu}$, Se and Fe and metal oxide NPs, such as silver oxide $\left(\mathrm{Ag}_{2} \mathrm{O}\right)$ copper oxide $(\mathrm{CuO})$, zinc oxide $(\mathrm{ZnO})$, titanium oxide $\left(\mathrm{TiO}_{2}\right)$, manganese oxide $\left(\mathrm{MnO}_{2}\right)$, magnesium oxide $(\mathrm{MgO})$, iron oxide $\left(\mathrm{Fe}_{2} \mathrm{O}_{3}\right)$, etc., have been fabricated using bacterial cells as a bionanofactory [5]. These NPs can be used in diverse fields, including the production of third generation biosensors [37], biofilm development [38], biolabeling and cell imaging [39], sensoristic devices [40] and diagnostics [41]. Moreover, biofabricated NPs showed promising applications as anticancer agents [31,42-48], antimicrobials [31,42, 43,49-52], antioxidants [44], anticoagulants [46] and antimigration and antiproliferative agents [45].

\subsubsection{Metal Nanoparticles \\ Silver Nanoparticles (AgNPs)}

It has been observed that the synthesis of AgNPs has increased immensely due to its wide range of applications in different fields [53]. As already mentioned, bacteria have an immense potential to withstand abiotic stresses and have the specific ability to reduce heavy metals into NPs. For instance, some of the bacteria, such as Pseudomonas stutzeri (facultative aerobe) and P. aeruginosa (facultatively anaerobe), can grow and survive at high concentrations of metals, including heavy metals [54,55].

The most commonly explored bacterial species for the synthesis of AgNPs include Escherichia coli, Lactobacillus sp., Bacillus cereus, Acinetobacter sp., Pseudomonas sp., Corynebacterium sp. and Klebsiella pneumonia [32,56,57]. Klaus-Joerger et al., 1999 were the first to report the fabrication of AgNPs (size less than $200 \mathrm{~nm}$ ) using the bacterial strain Pseudomonas stutzeri AG259 [58]. They observed that Pseudomonas stutzeri AG259 has the ability to accumulate Ag atoms in the cellular periplasmic space and can be used to synthesize different sizes of AgNPs (larger size, up to $200 \mathrm{~nm}$ ) when placed in a concentrated solution of $\mathrm{AgNO}_{3}(50 \mathrm{mM})$. The difference in size of NPs was due to the incubation of bacterial cells to different metal conditions. Such types of bacterial strains can be used for the industrial 
recovery of Ag. However, the exact process of the fabrication of AgNPs by this bacterial strain is still not clear. Nair and Pradeep (2002) demonstrated that a common bacterial strain of Lactobacillus found in buttermilk could be deployed for the fabrication of Au and AgNPs [59].

Shahverdi et al., 2007 reported the quick production of AgNPs by reduction of aqueous Ag ions using supernatants from cultures/cell-filtrate of Escherichia coli, Klebsiella pneumoniae and Enterobacter cloacae [60]. They observed that cell-filtrate rapidly reacted with Ag ions, and AgNPs were produced within $5 \mathrm{~min}$ of reaction. However, among the different bacteria used, the supernatant from Enterobacter cloacae (Enterobacteriaceae) was found to be most potent for the speedy fabrication of AgNPs [61]. Kalimuthu et al., 2008 studied the formation of AgNPs using B. licheniformis and observed that the biomass of B. licheniformis reduced the Ag ions (aqueous) into AgNPs [62]. The enzyme nitrate reductase led to the biosynthesis of stable NPs within $24 \mathrm{~h}$ of reaction. Hence, to enhance the speed of the process, it is very important to use suitable microbe(s).

In another study, Parikh et al., 2008 studied the molecular mechanism of biofabrication of AgNPs in Morganella sp. RP-42 extracted from insect midgut. They identified three homologous genes (silE, silP, and silS) in this bacterium [63]. They further illustrated that the silE gene isolated from Morganella sp. has 99\% sequence homology with the previously discovered silE gene which encodes a periplasmic silver-binding protein. Morganella sp. RP42 was successfully used for the fabrication of extracellular crystalline AgNPs (size $20 \mathrm{~nm}$ ). This is a unique report which suggests the molecular evidence of Ag resistance in bacterium and can be deployed in the fabrication of NPs [63]. In another study, Mokhtari et al., 2009 studied the effect of variable visible-light irradiation on the synthesis of AgNPs by using the supernatant obtained from cultures of Klebsiella pneumoniae and aqueous $\mathrm{AgNO}_{3}$ [64]. They fabricated AgNPs of a consistent size (average size of $3 \mathrm{~nm}$ ) and shape. Similarly, Nanda and Saravanan (2009) obtained AgNPs by extracellular reduction of aqueous Ag ions in bright conditions for $5 \mathrm{~min}$, using the supernatant obtained from cultures of Staphylococcus aureus [65].

Ramanathan et al., 2010 studied the effect of temperature on the biosynthesis of AgNPs using the bacterium Morganella psychrotolerans. The authors standardized the different growth attributes and studied their effect on the morphology of newly synthesized AgNPs [66]. They observed that at a temperature of $25^{\circ} \mathrm{C}$, a combination of spherical nanoparticles and triangular and hexagonal nanoplates were formed, while at a temperature of $20^{\circ} \mathrm{C}$, spherical AgNPs (size 2-5 nm) were obtained. When the temperature was further decreased from 20 to $15^{\circ} \mathrm{C}$, it resulted in the formation of a combination of spherical NPs and nanoplates. When the temperature was further reduced to $4{ }^{\circ} \mathrm{C}$, only a few larger sized spherical NPs (70-100 nm in size) were produced. This showed that the incubation temperature influences the size and symmetry of NPs. Hence, it is necessary to standardize reaction conditions for obtaining desired NPs.

In another study, Prakash et al., 2011 investigated the extracellular synthesis of spherical AgNPs (size 10-30 nm) using Bacillus cereus. The antibacterial effect of fabricated AgNPs was also studied against E. coli (Gram-ve) and Streptococcus (Gram+ve) using concentrations of AgNPs, and it was found that AgNP concentrations as low as 50 ppm could effectively check the bacterial growth [67]. Sunkar and Nachiyar (2012) studied the potential of the Bacillus species towards the synthesis of AgNPs and observed that the Bacillus species fabricated the AgNPs (size 10 to $20 \mathrm{~nm}$ ) extracellularly and reduced the Ag ions in solution [68].

It has been observed that bacterial strains that thrive in various extreme habitats can be used for the biosynthesis of NPs. Moreover, different parameters also effect the biosynthesis of NPs from microbes. Lin et al., 2001 demonstrated that the formation of NPs via reduction involves many factors, including desired environmental attributes ( $\mathrm{pH}$ and temperature) and availability of organic functional groups on the cell wall of bacterium which initiate/induce the reduction of metal ions [69]. Thus, the shape, symmetry, composition and size of NPs can be governed by the environmental conditions, such as culture 
medium, temperature, reactant concentrations, reaction time, $\mathrm{pH}$ and metallic salt to be reduced [59,70-72]. For instance, Bacillus cereus isolated from soil contaminated with heavy metal was successfully used for the extracellular biofabrication of AgNPs at standard temperature [29]. These biosynthesized AgNPs were reported to be employed in an array of applications as they exhibited good surface plasmon polariton properties. In another study, Kulkarni et al., 2015 observed that the radiation resistant strain of bacterium Deinococcus radiodurans reduces the $\mathrm{AgCl}$ solution and biofabricates extracellular AgNPs [73]. In a recent work, Yumei et al., 2017 observed the effect of temperature, $\mathrm{pH}$ and metal ion concentration on the biofabrication of AgNPs using Arthrobacter sp. They elucidated that at $7-8 \mathrm{pH}$ and $70^{\circ} \mathrm{C}$, Arthrobacter sp. fabricated face centered cubic AgNPs (size 9-72 nm) at a lower concentration of $\mathrm{AgNO}_{3}(1 \mathrm{mM})$ [74], while at the same temperature and at a higher concentration of $\mathrm{AgNO}_{3}(3 \mathrm{mM})$, Arthrobacter sp. fabricated bunches of AgNPs. Moreover, it was observed that the AgNPs were only synthesized at $\mathrm{pH} 7-8$, and at $\mathrm{pH}$ less than 5 and more than 8 , NP synthesis ceased. Furthermore, it was reported that when the incubation temperature was increased from 70 to $90{ }^{\circ} \mathrm{C}$, the fabrication time of NPs was also reduced from 10 to $2 \mathrm{~min}$. This work demonstrated the direct influence of reaction conditions on the biosynthesis of NPs [74].

The use of genetically engineered microorganisms for the fabrication of homogenous NPs of a desired shape and size is a novel strategy. Recently, approaches such as the discovery of genes responsible for the fabrication of nanoparticles, the introduction of foreign gene and cellular reprogramming have been under investigation for the improvement of wild type strains of microorganisms for the biogeneration of NPs with desired characteristics [75]. For instance, Lin et al., 2014 investigated that the CusCFBA silver/copper efflux system present in $E$. coli strain (116AR) governs the expression of genes of membrane proteins. When this strain of E. coli (116AR) was exposed to $\mathrm{AgNO}_{3}$ for a long time, it accumulated the AgNPs in its periplasmic space [76]. Similarly, Ramanathan et al., 2013 demonstrated the fabrication of AgNPs using a mutant strain of the E. coli (silver-resistant)expressing CusCFBAAg/Cu system. The mutant strain accumulated the AgNPs in the periplasm [77]. Recently, Yuan et al., 2019 also reported the fabrication of AgNPs by using a transformed strain of E. coli containing metallothionein in the gene from Candida albicans. The authors concluded that the transformed E. coli can be further used for the enhanced production AgNPs [78].

Jin-Zhou et al., 2000 found that the functional groups that occur on the cell wall of dried biomass of the Bacillus megaterium D01 and Lactobacillus sp. A09 bacteria reduce the Ag ions and facilitate the fabrication of AgNPs [79]. Ahmad et al., 2003 biosynthesized AgNPs based on the process of NADH-dependent reductase enzyme, which releases electrons and oxidizes to NAD in the bacterium Pseudomonas stutzeri AG259 [80]. Cynobacteria have also been successfully used for the biosynthesis of AgNPs via enzymatic reduction. For example, Lengke et al., 2007 demonstrated the biosynthesis of AgNPs using a filamentous cynobacteria Plectonema boryanum UTEX 485. In this study, the cynobacteria were incubated with $\mathrm{AgNO}_{3}$ solutions for 28 days at $25-100{ }^{\circ} \mathrm{C}$. The interaction between $\mathrm{AgNO}_{3}$ solutions and cynobacteria leads to the formation of up to 200-nm-sized octahedral Ag platelets and spherical AgNPs [81].

\section{Gold Nanoparticles (AuNPs)}

The bacterial cell machinery has also been utilized for the biofabrication of AuNPs by employing microbes [82]. Beveridge and Murray (1980), for the first time, demonstrated the intracellular fabrication of AuNPs by employing the bacteria Bacillus subtilis 168 and observed the existence of octahedral AuNPs (5-25 nm) [83]. As already mentioned, that medium conditions largely influence the synthesis of NPs. Konishi et al., 2004 studied the biosynthesis of AuNPs using the Shewanella algae and the effect of solution $\mathrm{pH}$ on the size and site of NP synthesis [84]. Mesophilic bacterium Shewanella algae were incubated in a medium at different $\mathrm{pH}$ levels. It was observed that the $\mathrm{pH}$ of solution affects the size and site of the NPs in Shewanella algae. The AuNPs of size 10-20 nm were formed in the 
periplasmic space of bacterium when the $\mathrm{pH}$ of the solution was 7.0, while 50-500- nm-sized AuNPs were accumulated extracellularly when the $\mathrm{pH}$ of the solution was dropped to 1. Similarly, He 2007 also studied the effect of $\mathrm{pH}$ on the size and shapes of AuNPs using the bacterium Rhodopseudomonas capsulata. They used an aqueous chloroauric acid $\left(\mathrm{HAuCl}_{4}\right)$ solution with different $\mathrm{pH}$ (4-7) for the synthesis of AuNPs using the biomass of R. capsulata. They reported that spherical AuNPs $(10-20 \mathrm{~nm})$ were produced when the solution $\mathrm{pH}$ was 7.0, while $\mathrm{Au}$ nanoplates were formed when the $\mathrm{pH}$ of the solution was 4.0. Hence, the $\mathrm{pH}$ of the solution is a governing factor which controls the shape and site of the biosynthesis of AuNPs [22]. The same study described the effect of $\mathrm{pH}$ and metallic ion concentration on the morphology of biosynthesized AuNPs using Rhodopseudomonas capsulata. The authors reported that at lower concentrations of $\mathrm{AuCl}_{4}$ and at $6.0 \mathrm{pH}$, spherical AuNPs (size 10 to $20 \mathrm{~nm}$ ) were synthesized, while at higher concentrations of $\mathrm{AuCl}_{4}$, gold nanowires were formed at a similar $\mathrm{pH}$ of 6.0. These findings are in accordance with the observations of Klaus et al., 1999, who reported that the size of NPs is affected by variations in incubation conditions [58]. Husseinyet al., 2007 demonstrated the extracellular synthesis of AuNPs using Pseudomonas aeruginosa enzymes [85]. However, in another study it has been shown that the bacterial enzymes do not participate in the synthesis of AuNPs [86]. For instance, Liu et al., 2009 reported the use of dried cells of Bacillus megaterium for the nonenzymatic synthesis of AuNPs [87]. Similarly, Sneha et al., 2010 also observed the nonenzymatic reduction process in the production of NPs in bacterium Corynebacterium sp. [86]. On the other hand, Correa-Llantén et al., 2013 demonstrated the enzymatic-reduction-mediated intracellular biosynthesis of quasihexagonal shaped and 5-50-nm-sized AuNPs using the bacterium Geobacillus sp. strain ID17 [88]. They concluded that during the metallic reduction, NADH acts as a cofactor, and cellular enzymes catalyze the biosynthesis process of AuNPs. In another study, Srinath et al., 2018 reported the biosynthesis of 20-25-nm-sized, well-dispersed AuNPs using the bacterium Bacillus subtilis. They concluded that these AuNPs could be efficiently catalyzed by the decomposition of methylene blue and could also be used for the bioremediation of other toxic dyes [89].

Different groups of cyanobacteria have also been used for the biosynthesis of AuNPs. Lengkeet al., 2006 and Brayneret al., 2007 have exploited Plectonema sp. for the fabrication of AuNPs [90,91]. Govindaraju et al., 2008 observed that Spirulina platensis (single-cell protein) fabricated AuNPs and Au core-Ag shell NPs [92].

Genetically engineered strains have also been successfully used for the biofabrication of AuNPs. For example, Attaran et al., 2016 demonstrated the biosynthesis of AuNPs using different genetically engineered strains of microorganisms. Recombinant strains of $P$. Savastanoi, R. solanacearum, P. syringae and V. fischeri produced 40-, 15-, 30- and 20-nm-sized AuNPs at a neutral $\mathrm{pH}$. It was reported that the NADH-dependent reductase and NADH were responsible for the biosynthesis of AuNPs [93].

Other Important Metal Nanoparticles

Brock and Gustafson (1976) observed that when the bacteria Sulfolobus acidocaldarius, Thiobacillus thiooxidans and Thiobacillus ferrooxidans were grown on elemental sulfur containing energy sources, these bacteria can efficiently reduce the ferric ion to a ferrous state. T. thiooxidans also efficiently reduced the ferric iron aerobically at a low $\mathrm{pH}$ medium and produced stable ferrous iron [94]. The ferrous ions formed were also stable to auto-oxidation.

Some other reports are also available where the process of biomineralization results in the formation of NPs; for instance, Escherichia coli K12 synthesize Tellurium (Te) [95], stagnant cells of Geobacter metallireducens (strain GS-15) and Shewanella putrefaciens cause the enzymatic reduction of Tc (VII) [96], and Rhodospirillum rubrum, Enterobacter cloacae and Desulfovibriode sulfuricans reduce selenite to selenium (Se). It has also been reported that some of the bacteria can fabricate inorganic material NPs [97]. For example, Lovley et al., 1987 synthesized intracellular magnetite NPs using magnetotactic bacteria [97]. Mullen et al., 1989 observed that bacterial cells can efficiently bind to metallic cations and 
found that P. aeruginosa, E. coli, B. subtilis and B. cereus have a good ability to remove $\mathrm{Cu}^{2+}$, $\mathrm{La}^{3+}, \mathrm{Cd}^{2+}$ and $\mathrm{Ag}+$ from aqueous solution [98].

Watson et al., 1999 reported the biosynthesis of magnetic iron sulfide (FeS) NPs on the surfaces of sulfate-reducing bacteria. These highly magnetic FeS nanoparticles of $20 \mathrm{~nm}$ in size were isolated from the solutions using a 1 Tesla high gradient field. The magnetic NPs were biofabricated due to bacterial iron reduction and acted as a physical indicator of geological setting via biological activities [99]. Biosynthesized FeS magnetic NPs can adsorb an array of heavy metals and few anions; hence, they can be applied as a potential adsorbent of heavy metals in bioremediation. It has been observed that the biofabrication of magnetite NPs is quite slow and requires complete anaerobic conditions. However, Bharde et al., 2005 synthesized NPs of magnetite using the nonmagnetotactic bacteria Acinetobacter spp. in complete aerobic conditions [100]. The magnetite nanoparticles were synthesized extracellularly in aerobic conditions when incubated with aqueous iron precursors, and these NPs exhibited good magnetic properties. In another study, the strain of Lactobacillus was efficiently deployed for the fabrication of titanium NPs [101].

Semiconductor NPs have also been fabricated using bacterial cellular machinery. Cunningham and Lundie (1993) reported that when Clostridium thermoaceticum cells were incubated in a medium containing cysteine hydrochloride (sulfide and $\mathrm{CdCl}_{2}$ source), it results in the formation of CdS NPs in the medium as well as on the surface of the bacterial cells [102]. Sweeney et al., 2004 also documented the intracellular fabrication of semiconductor cadmium sulfide (CdS) NPs using E. coli. They observed that the incubation of $E$. coli with sodium sulfide $\left(\mathrm{Na}_{2} \mathrm{~S}\right)$ and cadmium chloride $\left(\mathrm{CdCl}_{2}\right)$ results in the fabrication of cadmium sulfide (CdS) nanocrystals [103]. However, the synthesis of the nanocrystals was largely influenced by the physiological parameters, and the maximum yield (20-fold) of the nanocrystals was observed when the bacterial cells entered into the stationary phase.

A quick biosynthesis technique for the fabrication of spherical CuNPs (size 8-15 nm) was demonstrated by Varshney et al., 2011 using Pseudomonas stutzeri (nonpathogenic bacteria). In the same study, they also synthesized cubical copper NPs (size 50-150 nm) from electroplating wastewater, using the P. stutzeri strain isolated from soil [104]. It has also been reported in various studies that the biomineralization of metal ions results in the formation of NPs; for example, Shewanella algae, Pantoea agglomerans, Lactobacillus acidophilus and Azoarcus sp. reduce selenite to Se [34,44,105]. The nanocrystals of $\mathrm{Fe}_{3} \mathrm{O}_{4}$ and/or $\mathrm{Fe}_{3} \mathrm{~S}_{4}$ are also known to be bacterial magnetosomes. Bacterial magnetosomes have been biofabricated using both nonmagnetotactic and magnetotactic bacteria via the biomineralization process [106]. These bacterial magnetosomes are of a narrow size, highly pure, have defined crystal morphology, are stable at an ambient temperature [107] and can be used for the production of chip-based biosensors for the determination of toxicity, for cancer treatment and in molecular imaging [108-110].

Various types of heavy metal nanoparticles (platinum $(\mathrm{Pt})$, tellurium $(\mathrm{Te})$, palladium (Pd), etc.) have also been synthesized for specific applications in various fields. For instance, Zonaro et al., 2017 demonstrated that the bacterium Ochrobactrum sp. can be used to convert toxic tellurite oxyanions into useful TeNPs [111]. In another recent study, electrochemically active biofilms of the bacterial strain Shewanella loihica PV-4 were used to synthesize Pt and PdNPs (size 2-7 nm) [112].

Similar to Ag and AuNPs, some other important NPs like CdS, Cu and magnetic NPs have also been synthesized using genetically engineered strains of bacteria. For instance, Kang et al., 2008 used a recombinant strain of E. coli (JM109) having altered gammaglutamylcysteine synthetase and phytochelatin synthase genes (from Schizosaccharomyces pombe) for the production of cadmium sulfide (CdS) nanocrystals [26]. Similarly, Chen et al., 2009 also reported the fabrication of CdSNPs using two recombinant strains of E. coli (strain ABLE C) and observed that the rate of production of NPs using an engineered strain of E. coli was around 2.5 times better than the wild-type strain [113]. In another study, Jung et al., 2012 demonstrated the biofabrication of homogenous magnetic NPs using a recombinant $E$. coli strain expressing metallothionein and phytochelatin synthase 
genes [114]. Kolinko et al., 2014 studied the different genes (mamAB, mamGFDC, mamXY, and mms6) responsible for the biomineralization of magnetosome and the pathway of magnetite NP synthesis in the bacterium Magnetospirillum gryphiswaldense. The authors transferred the magnetosome biomineralization pathway (mam genes) into a heterologous host Rhodospirillum rubrum and fabricated magnetite NPs of $24 \mathrm{~nm}$ in size encapsulated by the protein shell [115]. In a recent study, Choi et al., 2018 demonstrated the biosynthesis of more than 60 different nanomaterials using genetically engineered Escherichia coli and concluded that the expression of the metal reductase gene in a recombinant strain of Escherichia coli could be employed for the biosynthesis of various chalcogenides, such as cadmium selenide, zinc sulfide and cadmium sulfide [116].

\subsubsection{Metal Oxide Nanoparticles}

Apart from metal NPs, bacteria have also been used to biosynthesize metal oxide $\mathrm{NPs}$, such as $\mathrm{Ag}_{2} \mathrm{O}, \mathrm{CuO}, \mathrm{ZnO}, \mathrm{TiO}_{2}, \mathrm{MnO}_{2}, \mathrm{MgO}$ and $\mathrm{Fe}_{2} \mathrm{O}_{3}$, which have a wide range of applications in the food industry, biomedicine, biosensors, optoelectronics, sunscreens and antimicrobial agents. For instance, spherical and triangular $\mathrm{Ag}_{2} \mathrm{ONPs}$ (size 2-20 nm) were successfully synthesized using Ag-resistant Lactobacillus mindensis isolated from an X-ray fixer solution [117]. The green-synthesized $\mathrm{Ag}_{2} \mathrm{ONPs}$ have strong antimicrobial activity and can be used in wound healing and skin creams for treatment of bacterial infection [118]. Vithiya et al., 2014 also reported that spherical $\mathrm{Ag}_{2} \mathrm{ONPs}$ (size 10-40 nm) biofabricated using Bacillus thuringiensis SSV1 exhibited strong antimicrobial activity against both Gramnegative (E. faecalis, E. coli, P. mirabilis, Pseudomonas sp.) and Gram-positive (S. aureus) bacteria [119]. CuONPs are another class of important metaloxide NPs which have a wide range of biological properties [120]. In a unique study, Hassan et al., 2019 extracellularly biofabricated CuONPs from two isolates of actinobacteria Streptomyces sp. (isolates Oc-5 and Acv-11) extracted from the medicinal plant Oxalis corniculata L. The spherical 78-80-nm-sized CuONPs obtained in this study showed excellent antibacterial, antifungal and antioxidant activity [121]. In a recent report, CuONPs have been synthesized using a cell-free supernatant of the marine bacterium Streptomyces sp. MHM38 [122]. The antimicrobial activity of spherical CuONPs (size 1.72-13.49 nm) was tested against different bacteria (E. coli ATCC 8939, E. faecalis ATCC 29212, P. aeruginosa ATCC 9027, S. typhimurium ATCC 14028), fungi (A. niger, F. solani, R. solani) and yeast (C. albicans ATCC 10237). It was concluded that $\mathrm{CuONPs}$ showed maximum antimicrobial activity against $C$. albicans ATCC 10237. ZnONPs have been widely studied and green synthesized due to their vast applications in biomedicine, the food industry, agriculture and cosmetics. Recently, Mohd Yusof et al., 2020 deployed the supernatant and cell biomass of the zinc-tolerant bacteria Lactobacillus plantarum TA4 in order to synthesize ZnONPs. TEM analysis suggested the biosynthesis of irregularly shaped ZnONPs (size $191.8 \mathrm{~nm}$ ) using the cell biomass and flower-like pattern ZnONPs (size $291.1 \mathrm{~nm}$ ) using a cell-free supernatant of bacteria. The antimicrobial activity of biosynthesized ZnONPs was studied against Gram-positive (S. epidermidis and S. aureus) and Gram-negative (Salmonella sp. and E. coli), and it was observed that ZnONPs were more effective against Gram-positive bacteria [123]. Another amnestic work reports the biofabrication of $\mathrm{ZnO}, \mathrm{MnO}_{2}$ and $\mathrm{MgONPs}$ by deploying a rhizophytic bacteria Paenibacillus polymyxa strain Sx3 [124]. TEM and SEM analysis revealed that the ZnONPs (size 56.1-110.0 nm), MgONPs (size 10.1-18.8 nm) and $\mathrm{MnO}_{2} \mathrm{NPs}$ (size 19.8-63.9 nm) were cubic, sheet-like and spherical in shape, respectively. All three metal oxide NPs exhibited significant antimicrobial activity against the bacterium Xanthomonas oryzae pv. Oryzae (Xoo) responsible for bacterial leaf blight in rice [124]. $\mathrm{TiO}_{2}$ is another important metal oxide NP which has high refractive index $(n=2.4)$, is highly stable and possesses specific magnetic, optical, electrical and thermal properties [125]. Due to these unique features, $\mathrm{TiO}_{2} \mathrm{NPs}$ finds applications in electronic devices, $\mathrm{PV}$ shell, sensing instruments, splitting and photocatalytic degradation [126,127]. An interesting study showed that biosynthesized $\mathrm{TiO}_{2} \mathrm{NPs}$ using $B$. amyloliquefaciens exhibited reasonable photocatalytic activity against the textile dye Reactive Red 31 (RR31) [128]. The spherical $\mathrm{TiO}_{2} \mathrm{NPs}$ (size 
22.11-97.28 nm) were doped with metals, such as $\mathrm{La}, \mathrm{Zn}, \mathrm{Pt}$ and $\mathrm{Ag}$, to increase the photocatalytic activity of biosynthesized $\mathrm{TiO}_{2} \mathrm{NPs}$. It was observed that $\mathrm{TiO}_{2} \mathrm{NPs}$ doped with $\mathrm{Pt}$ exhibited higher photocatalytic activity (90.98\%) against RR31 dye than the undoped ones (75.83\%). In a unique report, a consortium of three bacteria (Micrococcus aloeverae, Micrococcus lylae, Cellulosimicrobium sp.) isolated from the rhizosphere of sorghum plant along with root extract of sorghum was used to synthesize $\mathrm{TiO}_{2} \mathrm{NPs}$ [129]. The enzyme glucosidase present in bacteria acted as bioreducing agent. TEM and FTIR analysis confirmed the biosynthesis of nanospheres of $\mathrm{TiO}_{2} \mathrm{NPs}$ (size 14-17 nm). The biosynthesized $\mathrm{TiO}_{2} \mathrm{NPs}$ exhibited excellent photocatalytic activity against methyl orange (MO) dye and degraded 99\% of MOdye; thus, they can be used in the bioremediation of organic dyes. Halomonas elongata (strain IBRC-M 10214), a Gram-negative proteobacteria, was successfully deployed for the green synthesis of $\mathrm{TiO}_{2} \mathrm{NPs}$ and ZnONPs [130]. FTIR and SEM analysis showed the formation of well-dispersed spherical $\mathrm{TiO}_{2} \mathrm{NPs}$ (size $104.63 \mathrm{~nm}$ ) and $\mathrm{ZnO}$ NPs (size $18.11 \mathrm{~nm}$ ). The antimicrobial activity of both the metal oxide NPs was tested against $S$. aureus ATCC 43300 (Gram-positive) and E. coli ATCC 25922 (Gram negative). The ZnONPs exhibited strong antimicrobial activity against both types in comparison to $\mathrm{TiO}_{2} \mathrm{NPs}$. In a recent report, Streptomyces sp. HC1 isolated from soil was used for the synthesis of well-dispersed spherical $\mathrm{TiO}_{2} \mathrm{NPs}$ (size 30-70 nm) that exhibited strong antimicrobial activity against $E$. coli (ATCC 35218) and S. aureus (ATCC 29213) and a reasonable antibiofilm activity against P. aeruginosa ATCC 27853 [131]. Iron oxide NPs (IONPs) are also important metal oxide NPs which have specific magnetic properties and have applications in imaging, targeted drug delivery, bioremediation and antimicrobial and antifungal activity. The extracellular biofabrication of IONPs $\left(\mathrm{Fe}_{3} \mathrm{O}_{4}\right)$ has been successfully achieved using $B$. subtilis extracted from soil [132]. SEM analysis confirmed the formation of spherical 60-80-nm-sized NPs of $\mathrm{Fe}_{3} \mathrm{O}_{4}$. In a recent report, the antibacterial, antioxidant and cytocompatibility properties of IONPs biosynthesized using Proteus vulgaris ATCC-29905 were successfully analyzed [133]. The spherical IONPs (size 19.23-30.51 nm) showed strong antimicrobial activity against $S$. aureus (methicillin resistant), showed an antioxidant property, inhibited the migration of HT-29 cancer cells and exhibited a strong anticancer property against U87 MG-glioblastoma cancer cells.

\subsubsection{Organic Nanoparticles}

It has been reported that the extracellular polymeric substances (EPS) of bacteria can be deployed as an effective capping agent and bioreductant for the biofabrication of NPs from metal ions [134-136]. For instance, Mehta et al., 2014 used extracellular polymeric substances (EPS) extracted from the marine bacterium Alteromonas macleodii for the biofabrication of AgNPs [135]. Various mechanisms involved in the biofabrication of NPs by bacterial cells have been recently reported. It has been proposed that the intracellular or extracellular biosynthesis of NPs is a part of a cellular detoxification mechanism of bacterial cells via an enzymatic reduction which results in confirmatory changes in metal ions solubility [5]. These confirmatory changes in metal ions solubility lead to changing the soluble toxic metal ions to innoxious insoluble NPs. Different biocatalysts involved in the intracellular and extracellular biofabrication of NPs include cellular transporters and oxidoreductase enzymes (such as cysteine desulfhydrase, NADPH-dependent sulfite reductase flavoprotein subunit and NADH-dependent nitrate reductase) [5].

Certain bacterial genera have the specific capability of the biofabrication of some organic nanostructures. For instance, the aerobic acetic bacteria of genus Gluconacetobacter efficiently biosynthesized bacterial nanocellulose (3D network of cellulose nanofibrils) which was more crystalline, mechanically stable and purer than nanofibrillated cellulose and nanocrystalline cellulose [24]. Hence, due to its specific properties, bacterial nanocellulose can be used as nanocomposite in biosensoristic applications and as a scaffold for tissue engineering and drug delivery systems and as an antimicrobial agent in biomedical applications [137-139]. Another example of an extracellular microbial biopolymer is found in exopolysaccharides, which has applications as a protection agent and as an 
adhesive of bacterial biofilm. Li et al., 2017 demonstrated that when a nanosized spherical exopolysaccharide was used with the bacteria Lactobacillus plantarum-605, it resulted in the rapid biofabrication of monodispersed Ag and AuNPs [23].

\subsection{Actinobacteria-Mediated Biosynthesis of Nanoparticles}

Actinobacteria is a phylum under the bacterial domain which mainly consists of Gram-positive bacteria. These bacteria may be found in aquatic or terrestrial habitats, may decompose dead organic matter or occur as symbionts fixing nitrogen for the plant. Actinobacteria also have the potential to synthesize different biologically active compounds and NPs through extracellular or intracellular routes [4]. However, the extracellular reduction method is mostly preferred for commercial applications. Otari et al., 2012 demonstrated that the enzymes present on the cell wall of Rhodococcus NCIM 2891 facilitate in the biomineralization of Ag ions and the intracellular synthesis of AgNPs [140]. The biofabricated AgNPs were $10 \mathrm{~nm}$ (average diameter) in size and spherical in shape as revealed from TEM analysis. However, in another finding, Karthik et al., 2014 reported the extracellular biosynthesis of AgNPs using the marine bacterium Streptomyces sp. LK-3. They observed that the reduction of Ag ions into stable AgNPs was mediated by NADH-dependent nitrate reductase through an electron transfer reaction [141]. These extracellularly biosynthesized AgNPs showed high antiparasitic activity against Haemaphysalis bispinosa and Rhipicephalus microplus. In 2016, Abd-Elnaby et al., 2016 isolated 41 actinomycetes from the Suez Gulf of the Red Sea and screened these strains for their capacity to synthesize AgNPs. The study concluded that among all the strains, the marine bacterium Streptomyces rochei MHM13 was the most competent in fabricating AgNPs [142]. These AgNPs showed high antibacterial properties against various bacteria, such as B. subtilis, E. coli, B. cereus, V. uvialis, $P$. aeruginosa and S. typhimurium [142]. Similarly, in a recent study, Buszewski et al., 2018 biofabricated stable AgNPs of spherical shape ( 8 to $48 \mathrm{~nm}$ size) using the acidophilic actinobacteria Streptacidiphilus durhamensis. The study concluded that the biofabricated AgNPs showed a higher antimicrobial activity than AgNPs synthesized via conventional methods against Proteus mirabilis, S. aureus and P. aeruginosa [20]. The higher antimicrobial activity of biofabricated AgNPs was due to the stabilization and capping of biofabricated AgNPs with different biologically active molecules. Similarly, Wypij et al., 2018 demonstrated the biosynthesis of spherical polydispersed AgNPs (5-20 nm) using the actinobacterial Streptomyces xinghaiensis OF1 strain [143]. The biosynthesized AgNPs along with antibiotics exhibited strong synergetic antibacterial activity against B. subtilis, P. aeruginosa, E. coli and S. aureus and antifungal activity against the yeasts Malassezia furfur and Candida albicans.

In another recent report, Bakhtiari-Sardari et al., 2020 biosynthesized AgNPs using the two actinobacterial strains Streptomyces sp. OSIP1 and Streptomyces sp. OSNP14 [144]. These cold-tolerant strains produced small AgNPs of $8 \mathrm{~nm}$ (OSIP1) and $15 \mathrm{~nm}$ (OSNP14) in size, which exhibited strong antibacterial activity against Pseudomonas aeruginosa and strong anticancer activity against mouse colorectal carcinoma cells (CT26). These AgNPs, synthesized from different strains, showed similar biological activity although they had different sizes. Gold NPs have also been successfully synthesized using actinobacteria. Ahmad et al., 2003 synthesized uniform-sized AuNPs using the extremophilic actinobacteria Thermomonospora sp. and concluded that the enzymatic process of bacterium results in metal ions reduction and the stabilization of newly formed AuNPs [80]. Moreover, it was observed that Thermomonospora sp. can also fabricate the monodisperse AuNPs in extreme biological conditions, such as elevated temperature and high alkalinity [145]. In another study, Ahmad et al., 2003 reported that Rhodococcus sp., an alkalotolerant bacteria, can tolerate high metal ion concentrations $\left(10^{-3} \mathrm{M} \mathrm{HAuCl}_{4}\right)$ during the biofabrication of AuNPs. The authors reported that Rhodococcus sp. Produced monodisperse AuNPs $(5-15 \mathrm{~nm})$ intracellularly. The cells of bacterium continued growth even in the higher Au ion concentration and after the biofabrication of AuNPs [146]. He et al., 2007 reported that at lower concentrations of metal ions $\left(2.5 \times 10^{-4} \mathrm{M} \mathrm{HauCl}_{4}\right)$, Rhodopseudomonas cap- 
sulata biosynthesized spherical AuNPs (size 10-20 nm), while at higher concentrations, it produced nanowires (diameter between 50 and $60 \mathrm{~nm}$ ) [147].

Actinobacteria have also been successfully deployed for the synthesis of other NPs [148, 149]. For example, Ranjitha and Rai (2017) documented the first report on the extracellular biosynthesis of AuNPs using actinobacteria Streptomyces griseoruber isolated from the soil. Gold NPs of $5-50 \mathrm{~nm}$ in size produced via bioreduction exhibited strong catalytic activity for the decomposition of methylene blue [148]. In an interesting study, Hassan et al., 2018 biosynthesized CuNPs using the endophytic actinobacterial strain Streptomyces capillispiralis Ca-1, isolated from the medicinal plant Convolvulus arvensis L. The biofabrication of CuNPs was affirmed by a visual change in the color of biomass filtrate from light blue to greenish brown [149]. TEM analysis confirmed the production of spherical monodispersed CuNPs having a size of $3.6-59 \mathrm{~nm}$. FTIR analysis showed that the various bioactive functional groups present in actinobacteria help in the stabilization and formation of CuNPs. The biofabricated CuNPs exhibited good antimicrobial activity and antifungal activity.

\section{Fungi- and Yeast-Mediated Biosynthesis of Nanoparticles}

\subsection{Metal Nanoparticles}

Biofabrication of NPs using fungi is another biological method of NP synthesis. Fungi have a high cell wall binding potential with metal ions and have a higher potential to tolerate metal concentrations; hence, fungi can yield a higher number of NPs than bacterial cells [18]. The production of NPs using fungi is more efficient and inexpensive than bacteria, as fungi have a higher tendency to accumulate metals. Moreover, the treatment of biomass and downstream processing of NPs is simpler in the fungi-based biosynthesis of NPs. Therefore, fungi have been widely studied for the synthesis of different NPs, such as silver, gold, etc. In the past few years, it has been observed that the maximum work has been carried out on the extracellular fabrication of NPs using fungi, as it avoids the use of detergents; physical factors, such as ultrasound; and the doping of intracellular components, such as proteins, fats, nucleic acids, etc. [4]. For instance, Mishra et al., 2014 demonstrated the extracellular biosynthesis of AuNPs using the fungi Trichoderma viride and Hypocrea lixii and also described the effect of $\mathrm{pH}$ and temperature on the biosynthesis of AuNPs [150]. They observed that the cell-free extract of T. viride fabricated the AuNPs within 10 min of reaction at $30^{\circ} \mathrm{C}$, while $\mathrm{H}$. lixii synthesized the AuNPs at $100{ }^{\circ} \mathrm{C}$. The size of the newly synthesized AuNPs ranged between 20 and $30 \mathrm{~nm}$. It was also observed that T. viride synthesized AuNPs at a higher $\mathrm{pH}$ ( $\mathrm{pH} 7$ and 9) but failed to synthesize NPs at $\mathrm{pH}$ 5 at room temperature. Although $\mathrm{H}$. lixii failed to fabricate NPs at room temperature in the same $\mathrm{pH}$ range, it synthesized NPs when the reaction mixture was boiled at $100{ }^{\circ} \mathrm{C}$. The biosynthesized gold NPs exhibited strong antimicrobial and biocatalytic activities. Similarly, Metuku et al., 2014 fabricated AgNPs using the fungi Schizophyllum radiatum. It was observed that the fungi produced AgNPs of 10 to $40 \mathrm{~nm}$ in size via extracellular biomineralization, which showed strong antimicrobial properties against both Grampositive and -negative bacteria [151].

Factors such as medium $\mathrm{pH}$, reaction time and ionic concentrations largely influence the yield and size of NPs. Hence, many studies have been conducted to study the effect of these parameters on the biofabrication of NPs. For example, Bhargava et al., 2016 investigated the influence of ionic concentration and $\mathrm{pH}$ on the biosynthesis of AuNPs using the fungi Cladosporium oxysporum and reported the highest yield of AuNPs with $\mathrm{pH}$ 7.0, $1 \mathrm{mM}$ ionic concentration and 1:5 biomass to water ratio [152]. Similarly, Rajput et al., 2016 also studied the effect of $\mathrm{pH}$, temperature and isolate selection on the biosynthesis of AgNPs using 12 different isolates of the fungi Fusarium oxysporum. It was found that different medium $\mathrm{pH}(3,5,7$ and 9) affects the shape of AgNPs using Fusarium oxysporum 405. At $\mathrm{pH}$ 3.0, AgNPs of triangular, spherical, rod and other irregular shapes were produced, while at $\mathrm{pH} 5$ and 7, monodisperse and mostly spherical NPs were formed [153]. A further increase in $\mathrm{pH}$ up to 9 led to the fabrication of a combination of oblong and spherical NPs. The change in $\mathrm{pH}$ of the medium led to the formation of different sizes 
of NPs because the change in $\mathrm{pH}$ influences the basic or acidic nature of amino acids, which are involved in the fabrication of NPs [153-155]. Birla et al., 2013 studied the effect of temperature on the biosynthesis of AgNPs using Fusarium oxysporum and reported that a temperature of 40 to $60^{\circ} \mathrm{C}$ is optimal for the synthesis of AgNPs [155]. Similarly, Rajput et al., 2016 also studied the effect of different temperatures on the quantity of AgNPs produced from $F$. oxysporum 405 and found that the maximum NPs were formed at a temperature between 50 to $70{ }^{\circ} \mathrm{C}$, while minimum AgNP formation was observed at $25^{\circ} \mathrm{C}$. The incubation temperatures also affected the size of newly synthesized AgNPs. At the optimum temperatures $\left(50\right.$ to $\left.70{ }^{\circ} \mathrm{C}\right)$, small sized NPs $(10 \mathrm{~nm})$ were formed, while at $25^{\circ} \mathrm{C}$, AgNPs were more than $50 \mathrm{~nm}$ in diameter [153]. The biofabrication of other important NPs apart from AgNPs has also been explored using various fungal strains; for example, Kitching et al., 2016 demonstrated the biosynthesis of spherical and 16-19-nm-sized AuNPs from cell surface proteins isolated from Rhizopus oryzae. These biofabricated AuNPs were found to be stable and hemocompatible and therefore can be used for biocatalytic and biomedical applications [156].

In another study, El Domany et al., 2018 demonstrated the extracellular biofabrication of 10-30-nm-sized AuNPs using the edible fungi Pleurotus ostreatus and reported that the fabrication of AuNPs significantly affected by the salt concentration, temperature, $\mathrm{pH}$ and incubation time [157]. In this study it was reported that the rate of biofabrication of AuNPs was directly proportional to the incubation time, salt concentration and temperature. As the incubation time, salt concentration and temperature were increased to $12-48 \mathrm{~h}, 1-5 \mathrm{mM}$ and $30-40{ }^{\circ} \mathrm{C}$, respectively, the rate of AuNP biofabrication also increased. However, the maximum AuNPs were synthesized at pH 3.0. Neethu et al., 2018 demonstrated the green synthesis of AgNPs from the fungi Penicillium polonicum, isolated from the marine green alga Chetomorpha antennina, and concluded that the biosynthesized AgNPs showed strong antibacterial activity against the biofilm-forming multidrug-resistant bacterium Acinetobacter baumanii [158]. In a recent report, Clarance et al., 2019 reported the biosynthesis of 40-45-nm-sized AuNPs from the endophytic fungi Fusarium solani ATLOY-8, isolated from the plant Chonemorpha fragrans. The biosynthesized AuNPs were highly stable and showed good anticancerous activity against HeLa and MCF-7 cell lines [159]. Similarly, Munawer et al., 2020 reported the extracellular green synthesis of 5-10-nm-sized spherical AuNPs from the fungi Cladosporium sp., extracted from the medicinal plant Commiphora wightii, which showed excellent antiproliferative activity against the breast cancer cell line MCF-7 [160]. Similarly, Ramos et al., 2020 reported the extracellular biosynthesis of AgNPs from the fungi Trichoderma spp., extracted from seeds of plant Bertholletia excelsa (Brazil nut), and concluded that the biofabricated AgNPs had superior antibacterial activity against Gram-negative bacteria [161].

Yeasts have the potential to survive in a high concentration of metal ions and have the capability to deposit a high amount of metal ions from a medium [14]. This feature of yeast has been used by different researchers for the green synthesis of NPs [35,162, 163]. For instance, Apte et al., 2013 exploited the marine yeast Yarrowia lipolytica for the biosynthesis of AgNPs and concluded that melanin (a brown pigment found in yeast) was associated with green synthesis of AgNPs [162]. In a different study, Waghmare et al., 2015 demonstrated the extracellular biofabrication of 20-80-nm-sized AgNPs from the yeast strain Candida utilis NCIM 3469 and concluded that these biofabricated AgNPs exhibited a good antibacterial property against disease-causing strains of the bacteria P. aeruginosa, E. coli and S. aureus [35]. Similarly, AgNPs of $2-10 \mathrm{~nm}$ in size with strong antibacterial activity against K. pneumonia and S. aureus were biosynthesized from a yeast strain of Candida lusitaniae isolated from the gut of a termite [164]. Zhang et al., 2016 demonstrated, for the first time, the green synthesis of AuNPs from the yeast Magnusiomyces ingens LH-F1. They reported the biosynthesis of AuNPs of different sizes (hexagon, spheres and triangles) that showed strong reducing properties against nitrophenols [163]. Genetically engineered yeast has also been used for the fabrication of metal NPs. In the recent past, Elahian et al., 2017 successfully used the genetically altered yeast strain Pichia pastoris for the fabrication 
of AgNPs [165]. In this study, it was demonstrated that the genetically altered yeast strain Pichia pastoris transformed with an upregulated metal resistant gene from Mucor racemosus produced cytochrome b5 reductase enzyme, which reduces the metal ions and produces uniform (size 70-180 nm) and stable AgNPs. In another study, Sriramulu and Sumathi (2018) reported the biosynthesis of PdNPs from S. cerevisiae. The newly biosynthesized hexagonal PdNPs of $32 \mathrm{~nm}$ in size exhibited good catalytic activity against textile azo dye and degraded 98\% dye under UV light within 60 min of exposure [166].

\subsection{Metal Oxide Nanoparticles}

Like bacteria, fungi and yeast have also been explored for the synthesis of various important metal oxide NPs. Aluminum oxide $\mathrm{NPs}\left(\mathrm{Al}_{2} \mathrm{O}_{3} \mathrm{NPs}\right)$ are important metal oxide NPs which have significant antimicrobial properties against multidrug-resistant bacteria [167]. In a unique report, $\mathrm{Al}_{2} \mathrm{O}_{3} \mathrm{NPs}$ were biosynthesized using Colletotrichum sp. and were made functional using plant oils extracted from Citrus medica and Eucalyptus globules. The nanoactivated oils exhibited effective antimicrobial activity against food spoiling pathogens [168]. In an interesting study, ZnONPs were extracellularly biofabricated using Aspergillus terreus AF1 and were tested for their biomedical properties [169]. The A. terreus AF1 effectively reduced the $\mathrm{ZnO}$ to $\mathrm{ZnONPs}$, and FTIR analysis confirmed that the proteins secreted by $A$. terreus AF1 acted as a capping agent of the ZnONPs. These green-synthesized spherical ZnONPs (size 10-45 nm) exhibited strong antimicrobial activity against $P$. aeruginosa, $S$. aureus, B. subtilis and E. coli and a reasonable cytotoxic effect against Vero and Caco cell lines. Cotton fabric was blended with the ZnONPs, and the deposition of ZnONPS on the cotton fabric was confirmed by SEM. It was observed that this blend exhibited moderate antibacterial activity against E. coli and P. aeruginosa and also blocked the passage of UVA (76.3\%) and UVB (85.4\%) in comparison to untreated cotton fabric. In another important work, Mohamed et al., 2019 studied the effect of fungal strains on the morphology and bioactivity of ZnONPs. In this study, ZnONPs were synthesized using two fungi, A. niger strain (G3-1) and F. keratoplasticum strain (A1-3), isolated from soil. It was reported that ZnONPs of different morphology were synthesized using different fungal strains [170]. Hexagonal ZnONPs (size 10-42 nm) were fabricated using the F. keratoplasticum strain (A1-3) while nanorods (size 8-32 nm) were synthesized using the A. niger strain (G3-1). It was also reported that nanorod ZnONPs were more effective against both Gram-positive bacteria (B. subtilis and S. aureus) and Gram-negative bacteria (E. coli ATCC 8739 and P. aeruginosa ATCC 9027) than hexagonal ZnONPs. Hence, the bioactivity of NPs was governed by their shape and size due to the variation in physical and chemical properties. Recently, in a unique report, Sumanth et al., 2020 fabricated ZnONPs using Xylaria acuta isolated from the plant Millingtonia hortensis L.f. The hexagonal ZnONPs (size 34-55 nm) showed strong antimicrobial properties against the bacteria P. aeruginosa, E. coli, S. aureus and B. cereus and the fungi Cladosporium cladosporioides and good anticancer property against human MDA-MB 134 mammary gland carcinoma cells [171]. ZnO and CuONPs also act as good antibiofilm, antibacterial and antifungal agents against multidrug-resistant microbes and hence can be used as potent antimicrobial nanomaterials [172]. In a recent report, the efficiency of ZnONPs (size 9-35 nm) and CuONPs (size 10.5-59.7 nm) fabricated using $P$. chrysogenum as antibiofilm and antibacterial agents was tested [173]. It was reported that $\mathrm{CuONPs}$ showed higher antibacterial activity than ZnONPs against both Gram-positive and Gram-negative bacteria. In an interesting recent study, mycogenic $\mathrm{CuONPs}$ have been tested for their insecticidal and growth regulator activity in wheat (Triticum aestivum L.) storage [174]. Spherical CuONPs (size 14-47.4 nm) were synthesized using A. niger G3-1 and characterized using SEM, TEM, XRD and FTIR. The insecticidal property of CuONPs was tested during the storage of wheat, and it was reported that NP treatment leads to the mortality of grain insects Sitophilus granaries (55-94.4\%) and Rhyzopertha dominica (70-90\%). The CuONPs 50 ppm dose also significantly stimulated the growth and physiology of wheat grain germination. In a unique report, $\mathrm{CuO} / \mathrm{ZnO}$ nanocomposites were biofabricated using cell filtrate of Penicillium corylophilum As-1, and their photocatalytic activity was 
assessed against methylene blue dye [175]. It was reported that nanocomposites having $\mathrm{CuO}$ and $\mathrm{ZnO}$ in a ratio of 20:80 (size 10-55 nm) degraded 97\% of methylene blue dye. $\mathrm{TiO}_{2}$ is another important metal oxide which is naturally obtained from rutile, brookite or anatase minerals and has an array of applications in pharmaceuticals, photocatalytic activity, food, bioremediation, agriculture and cosmetics $[125,176]$. The photocatalytic and antimicrobial activity of spherical $\mathrm{TiO}_{2} \mathrm{NPs}$ (anatase, size $6.7 \mathrm{~nm}$ ) fabricated using Baker's yeast was tested against methylene blue dye and the Gram-positive bacteria C. albicans [176]. $\mathrm{TiO}_{2} \mathrm{NPs}$ efficiently degraded the methylene blue and significantly controlled the growth of Candida albicans. In a unique study, $\mathrm{TiO}_{2} \mathrm{NPs}$ synthesized using T. viride were used as biopesticides. The pupicidal, larvicidal and antifeedant properties of spherical $\mathrm{TiO}_{2} \mathrm{NPs}$ (size 60-86.67 nm) were tested against Helicoverpa armigera. It was reported that in a filter paper assay, Trichoderma viride-mediated $\mathrm{TiO}_{2} \mathrm{NPs}(100 \mathrm{ppm})$ showed significant biopesticidal activity and enhanced the mortality rate of $H$. armigera up to $100 \%$, while they did not exhibit any toxic effect against Eudrilus eugeniae (earthworm) [177]. Recently, the anticancer and antibacterial activity of $\mathrm{TiO}_{2} \mathrm{NPs}$ synthesized using Pleurotus djamor (an edible mushroom) has been studied, and it has been reported that $\mathrm{TiO}_{2} \mathrm{NPs}_{\mathrm{s}}(31 \mathrm{~nm})$ showed strong anticancer activity against A549 cancer cells and significant antibacterial activity against $C$. diphtheria, $S$. aureus and $P$. fluorescens [178]. IONPs have immense capabilities in biomedicine, environment, life science, agriculture, biosensors and storage [179]. Bhargava et al., 2013 biosynthesized cubic IONPs (size 60-70 $\mathrm{nm}$ ) deploying Aspergillus japonicus (AJP01). FTIR data affirmed that the biosynthesized IONPs were stabilized by the fungal proteins [180]. Recently, Mahanty et al., 2019 synthesized IONPs (size 2-16 nm) using manglicolous fungi (Fusarium incarnatum, Trichoderma asperellum and Phialemoniopsis ocularis) isolated from the waterlogged Sundarban (India). The role of these IONPs was also studied in the bioremediation of water containing chromium, and it was reported that the IONPs exhibited an excellent chemisorption property towards $\mathrm{Cr}(\mathrm{VI})$ with a 4.62 $\mathrm{mg} / \mathrm{g}$ adsorption capacity [181,182]. In a novel attempt, Vijayanandan et al., 2018 synthesized cobalt oxide NPs (CoONPs) using Aspergillus nidulans. The biosynthesized spinel CoONPs (size 20.29) were used in energy storage and showed a promising capacitance of $389 \mathrm{~F} / \mathrm{g}$ [183]. From the above reports, it can be concluded that fungi and yeast have immense potential for the green synthesis of NPs.

\section{Algae-Mediated Biosynthesis of Nanoparticles}

\subsection{Metal Nanoparticles}

Algae are autotrophic organisms and can easily grow on minimal medium supplements. Algae cells have different secondary metabolites and many biologically active compounds which act as capping agents during NP synthesis and make the algal cell a unique "nanofactory" for the synthesis of various NPs [184]. Dhas et al., 2014 extracellularly biofabricated $\mathrm{AgCl}$ NPs using the marine alga Sargassum plagiophyllum. TEM analysis confirmed the synthesis of spherical AgCl NPs of 21-48 nm in size [185]. The biofabricated $\mathrm{NPs}$ of $\mathrm{AgCl}$ showed reasonable antibacterial activity against E. coli. Similarly, Edison et al., 2016 demonstrated the biosynthesis of highly stable AgNPs using an extract of the marine alga Caulerpa racemosa (green algae). The newly synthesized AgNPs were $25 \mathrm{~nm}$ in size and exhibited excellent catalytic activity against methylene blue [186]. In another study, da Silva Ferreira et al., 2017 demonstrated the extracellular biosynthesis of $\mathrm{AgCl} \mathrm{NPs} \mathrm{using} \mathrm{a}$ dried biomass of the green unicellular alga Chlorella vulgaris. FTIR investigation of biosynthesized $\mathrm{AgCl} \mathrm{NPs} \mathrm{revealed} \mathrm{that} \mathrm{the} \mathrm{proteins} \mathrm{of} \mathrm{alga} \mathrm{were} \mathrm{the} \mathrm{chief} \mathrm{capping} \mathrm{agent} \mathrm{engaged}$ in the stabilization and formation of AgCl NPs [187]. TEM investigation showed that most of the $\mathrm{AgCl} \mathrm{NPs}$ were spherical in shape and $9.8 \mathrm{~nm}$ in size. The newly synthesized $\mathrm{AgCl} \mathrm{NPs} \mathrm{exhibited} \mathrm{strong} \mathrm{antimicrobial} \mathrm{activity} \mathrm{against} \mathrm{the} \mathrm{pathogenic} \mathrm{bacteria} \mathrm{S.} \mathrm{aureus}$ (Gram-positive) and K. pneumoniae (Gram-negative). Kim et al., 2018 also reported the extracellular biosynthesis of AgNPs using a cellular extract of the alga Laminaria japonica and concluded that the rate of the biosynthesis of AgNPs was significantly enhanced when L. japonica cellular extract was incubated with $\mathrm{AgNO}_{3}$ at $120^{\circ} \mathrm{C}$ [188]. In a recent report, 
Fatima et al., 2020 demonstrated the biosynthesis of spherical AgNPs using the red alga Portieria hornemannii [189]. The AgNPs exhibited good antimicrobial activity against the bacteria Vibrio parahaemolyticus, Vibrio anguillarum, Vibrio alginolyticus and Vibrio harveyii. In another recent report, Bhuyar et al., 2020 analyzed the biosynthesis of 25-60-nm-sized AgNPs using the marine microalga Padina sp. [190]. The AgNPs were uniform in size and exhibited strong antimicrobial activity against the pathogenic bacteria P. aeruginosa and $S$. aureus.

Reports are also available on the biosynthesis of AuNPs using algae. Senapati et al., 2012 reported the intracellular biosynthesis of AuNPs of 5-35 nm in size using the alga Tetraselmisko chinensis [191], while Singh et al., 2013 demonstrated the extracellular biosynthesis of 53-67-nm-sized AuNPs using the macroalga Padina gymnospora [192]. Dahoumane et al., 2016 demonstrated the biosynthesis of AuNPs using the microalga Euglena gracilis. The AuNPs were synthesized using cells of E. gracilis. It was observed that this microalga exhibited seven to eight times faster growth, which improved the kinetics, the colloidal stability and the yield of the biofabricated AuNPs (with variable shapes, including round, hexagons, pentagons, triangles and truncated triangles) [193]. In a different study, Ramakrishna et al., 2016 demonstrated the extracellular biosynthesis of AuNPs by employing a cellular extract of the brown algae Turbinaria conoides and Sargassum tenerrimum. High-resolution TEM investigation showed the biosynthesis of nearly spherical AuNPs of 27-35 nm in size [194]. The biofabricated NPs exhibited a good degradation ability against organic dyes and aromatic nitro compounds. Similarly, González-Ballesteros et al., 2017 also reported the extracellular synthesis of AuNPs using an extract of the brown macroalga Cystoseira baccata. The spherical AuNPs were stable and $8.4 \mathrm{~nm}$ in size. The AuNPs exhibited an acceptable cytotoxic effect towards the normal primary neonatal dermal fibroblast cell line PCS-201-010 and colon cancer cell lines Caco-2 and HT-29 [195].

PdNPs have also been synthesized using algal cellular machinery. Momeni and Nabipour (2015) demonstrated the biosynthesis of PdNPs using the marine alga Sargassum bovinum [196]. In an interesting study, Arsiya et al., 2017 reported the extracellular quick biosynthesis of PdNPs using a cellular extract of the green alga Chlorella vulgaris. The PdNPs were synthesized within $10 \mathrm{~min}$ of incubation with the extract of $C$. vulgaris. TEM analysis showed the biofabrication of uniform, circular, 5-20-nm-sized PdNPs [197]. In another study, Sayadi et al., 2018 demonstrated the extracellular biosynthesis of PdNPs using a cellular extract of the alga Spirulina platensis. TEM results revealed that the PdNPs were spherical in shape and were 10-20 nm in size. The biosynthesized PdNPs were successfully used in the bioremediation of lead [198].

\subsection{Metal Oxide Nanoparticles}

As discussed above, the microbial cellular factory has been successfully used for the synthesis of metal and metal oxide NPs. Algae have also been deployed for synthesizing different metal oxide NPs. Rajeshkumar (2018) extracellularly biofabricated ZnONPs using two marine brown algae, Turbinaria conoides and Padina tetrastromatica. The crystalline nature of newly synthesized ZnONPs was characterized by using XRD and SEM [199]. The biosynthesized ZnONPs exhibited strong antimicrobial activity against fish pathogens. In another similar study, Sanaeimehr et al., 2018 reported the extracellular biosynthesis of ZnONPs using an extract of the alga Sargassum muticum. The biofabricated ZnONPs exhibited strong antiapoptotic and antiangiogenic activity toward human liver cancer cell lines [21]. Khalafi et al., 2019 demonstrated the extracellular biosynthesis of ZnONPs using an extract of the green microalgae Chlorella. The biosynthesized ZnONPs were characterized using SEM and TEM. These monodispersed hexagonal-shaped ZnONPs had an average size of $20 \mathrm{~nm}$ and exhibited reasonable remediation properties against organosulfur pollutants [200]. In a unique study, $\mathrm{ZnO}$ nanorods were synthesized using carbohydrates extracted from the green algae Chlorella vulgaris. The $\mathrm{ZnO}$ nanorods (length $150 \mathrm{~nm}$ and width $21 \mathrm{~nm}$ ) showed an excellent screening effect against UVA and UVB and a strong antibacterial activity against both Gram-positive and Gram-negative bacteria [201]. 
In a recent report, $\mathrm{ZnONPs}$ have been biosynthesized using the blue green algae Arthrospira platensis [202]. The ZnONPs were characterized using FTIR, XRD and TEM. The spherical ZnONPs (size 30-55 nm) exhibited significant antimicrobial activity against E. coli, $B$. subtilis, P. aeruginosa, S. aureus and C. albicans. In a specific study, Sharma et al., 2018 biosynthesized $\mathrm{TiO}_{2} \mathrm{NPs}$ and a $\mathrm{TiO}_{2}$-graphene oxide (GO) nanocomposite using Chlorella pyrenoidosa (a green alga). The XRD and SEM analysis confirmed the formation of spherical $\mathrm{TiO}_{2} \mathrm{NPs}$ (size $50 \mathrm{~nm}$ ) and a sheet-like $\mathrm{TiO}_{2}-\mathrm{GO}$ nanocomposite. The photocatalytic activity of both nanostructures was tested and compared against crystal violet (CV) dye, and it was reported that the $\mathrm{TiO}_{2}$-GO nanocomposite more efficiently degraded the CV than the $\mathrm{TiO}_{2} \mathrm{NPs}$ [203]. El-Kassas et al., 2016 reported the green synthesis of IONPs $\left(\mathrm{Fe}_{3} \mathrm{O}_{4}\right)$ using two brown algae (seaweeds), Sargassum acinarium and Padina pavonica [204]. TEM analysis confirmed the formation of IONPs of 21.6-27.4 nm using S. acinarium and 10-19.5 nm using P. pavonica. The green-synthesized IONPs were then encapsulated in calcium alginates beads $(\mathrm{CAB})$ and were used for the bioremediation of lead $(\mathrm{Pb})$. It was reported that the IONPs-CAB synthesized using S. acinarium absorbed $78 \%$ of $\mathrm{Pb}$ while IONPs-CAB from $P$. pavonica removed $91 \% \mathrm{~Pb}$. The study affirmed the role of NPs in bioremediation. The algal cells have several secondary metabolites and many biologically active compounds which act as capping agents during NP synthesis and make them unique "nanofactories" for the synthesis of various NPs [184].

\section{Virus-Mediated Biosynthesis of Nanoparticles}

Viruses are covered with capsid proteins of nanoscale structures $(20-500 \mathrm{~nm})$, which provide appropriate tenets to metallic ions to interact with virus machinery [205]. The capsid protein can be modified via genetic engineering for the synthesis of nanomaterials, such as nanocomposites and nanoconjugates of metal NPs, for the treatment of cancer and targeted drug delivery [4]. Many reports are available where viruses have been successfully deployed for the biosynthesis of NPs. For instance, M13 bacteriophage has been successfully used as a template for the fabrication of semiconductor NPs of cadmium sulphide (CdS) and zinc sulphide (ZnS) [206]. Plant viruses are stable, easy to cultivate and nonpathogenic to animals and humans. Hence, plant viruses can also be deployed for the fabrication of NPs for use in humans and animals. For example, Slocik et al., 2005 synthesized AuNPs using cowpea chlorotic mottle viruses as a template [207]. Similarly, Kobayashi et al., 2012 demonstrated the green synthesis of uniform shaped AuNPs (size $5 \mathrm{~nm}$ ) using the tobacco mosaic virus (TMV) [205]. Cao et al., 2014 synthesized nanocarriers using the red clover necrotic mosaic virus (RCNMV), which were successfully tested for the regulated delivery of the drug doxorubicin for the treatment of cancer [208]. Similarly, Czapar et al., 2016 synthesized hollow nanotubes with a polyanionic interior surface using the tobacco mosaic virus (TMV) for the targeted delivery of the anticancer drug phenanthriplatin. In this study, the one-step mechanism for the loading of phenanthriplatin and its delivery using TMV nanotubes was successfully demonstrated in a mouse model [209]. In a similar report, Le et al., 2017 used nanocarriers synthesized through the potato virus $X$. They synthesized elongated lamentousnanocarriers for the targeted delivery of the drug doxorubicin for cancer treatment. These virus-mediated nanocarriers showed an increased penetration power in the tumor compared with spherical NPs [210]. In another study, Chen et al., 2018 reported the biosynthesis of the hepatitis E virus nanoparticle (HEVNP) using the hepatitis E virus capsule. In this study the HEVNP was coupled with a labeled near-infrared (NIR) fluorescence dye and breast cancer cell-specific ligand, LXY30. It was concluded that these biosynthesized HEVNPs could be deployed as multifunctional delivery carriers for tumor imaging, tissue targeting and therapeutic delivery [211].

In a recent study, Thangavelu et al., 2020 synthesized Au-Ag composite semiconductor NPs using the plant pathogenic squash leaf curl China virus (SLCCNV) [212]. The virus was used as a nanobiotemplate $(32 \mathrm{~nm})$ to synthesize the $\mathrm{Au}-\mathrm{Ag}$ nanomaterials. The $\mathrm{Au}-\mathrm{Ag}$ nanomaterial was tested for electrical conductivity using Keithley's picoammeter and the "lab on a chip" system. It was concluded that the hybrid nanomaterial ( $\mathrm{Au}-\mathrm{Ag}$ ) showed 
excellent semiconductive properties and good biocompatibility for biomedical applications. In the aforementioned reports, viruses have been successfully used as a template for the synthesis of NPs; however, virus-mediated NP synthesis still has certain limitations, such as large-scale application, biocompatibility, the requirement of a host for protein expression and under-defined methods for the synthesis of NPs.

\section{Applications of Nanoparticles}

Due to their unique size, shape, structure and specific biological, physical and chemical properties, nanoparticles are suitable candidates for various applications in different fields. (1) Biomedical: drug delivery, disease diagnosis, cancer therapy, antibacterial activity, etc.

(2) Food and agriculture: nutraceutical, food packaging, pesticides, nutrient availability, nanobiosensors for crop protection, nanoformulations of agrochemicals, nanodevices for the genetic engineering of plants, animal health, postharvest management, etc. (3) Environment: bioremediation, water treatment, biodegradable polymers, pollution monitoring sensors, UV protection, etc. [28,213] (Figure 3). The applications of microbially synthesized NPs in different fields are discussed in the following section of this review.

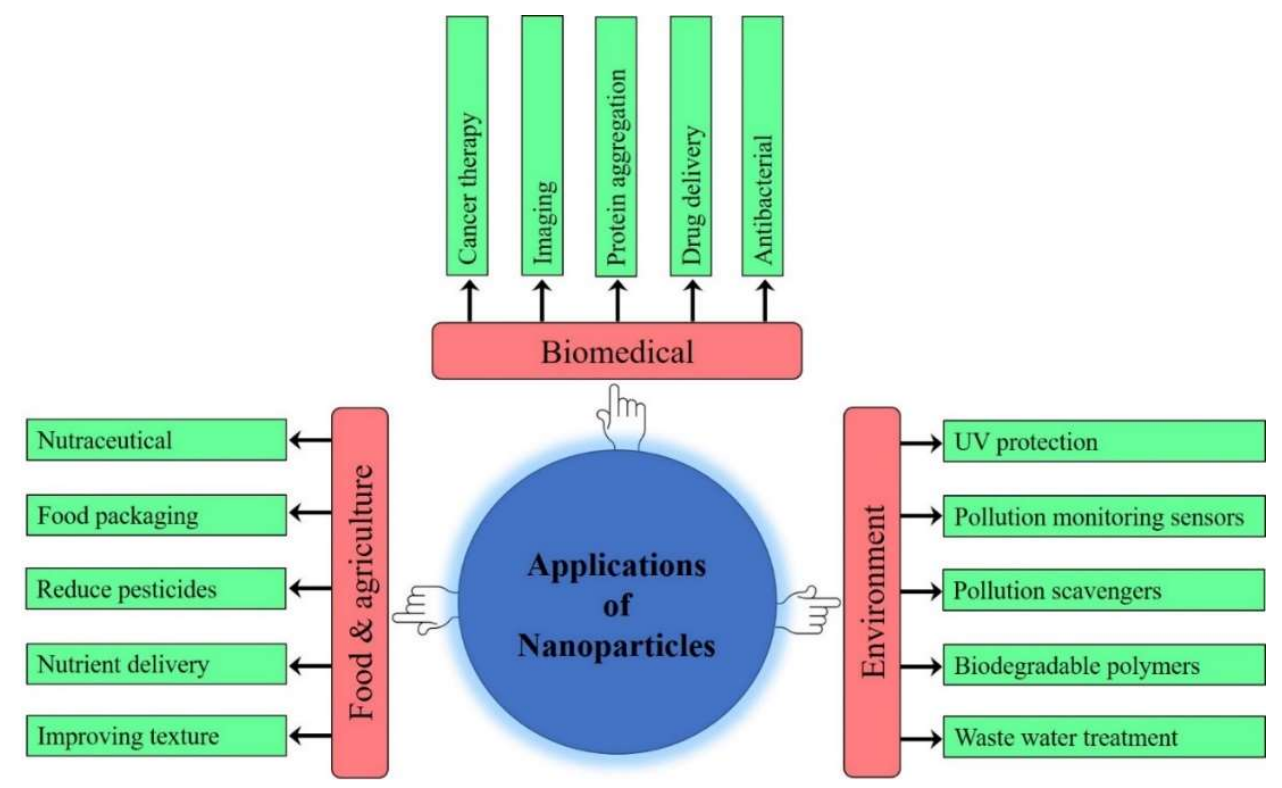

Figure 3. Applications of NPs in different fields.

\subsection{Biomedical Applications of Nanoparticles}

Pathogenic microbes develop resistance against antibiotics via changing their metabolic pathways and target sites [214]. Moreover, these microbes develop more pathogenicity and become resistant to antibiotics due to their continuous exposure [15]. Hence, it is essential to develop certain alternative, unconventional, powerful antimicrobial agents which are cheaper and safer. Biofabricated NPs have a larger surface area and smaller size. These properties allow NPs to efficiently interact with the microbial cell membrane and penetrate the cells to interfere with the metabolic pathways and DNA replication [15]. The antibacterial activities of different NPs have been reported in many studies.

Sondi and Salopek-Sondi (2004) studied the possible process of the antibacterial action of NPs, which involves the destruction of the cell membrane and cellular machinery via the formation of pits which culminate in the death of bacterial cells [215]. In addition to this, if the NPs are used along with traditional antibiotics, the antibacterial efficiency of NPs can be enhanced. For example, Banuet al., 2011 studied the combined effect of AgNPs (biofabricated using bacterium R. stolonifer) and antibiotics (ciprofloxacin, nitrofurantoin and carbenicillin) against bacterial species of the family Enterobacteriaceae (ESBL-strains). 
The decreasing order of the antibacterial activity was: nitrofurantoin $(50 \%$ efficacy) $>$ carbenicillin (33.56\% efficacy) > ciprofloxacin (30.53\% efficacy) [216]. Sunkar and Nachiyar (2012) studied the antibacterial activity of AgNPs synthesized from Bacillus cereus (using the agar-well diffusion method) against the disease-causing bacteria Staphylococcus aureus, Klebsiella pneumonia, Pseudomonas aeruginosa, Escherichia coli and Salmonella typhi. It was observed that AgNPs produced larger zones of inhibition in comparison to standard antibiotics (amoxicillin, streptomycin and ofloxacin) [68]. Singh et al., 2015 studied the synergetic effect of AgNPs obtained from Brevibacterium frigoritolerans in combination with the antibiotics oleandomycin, novobiocin, vancomycin, rifampicin, lincomycin and penicillin G [217]. They reported that the antimicrobial efficacy of all the antibiotics was enhanced against the disease-causing strains of Candida albicans, Bacillus anthracis, Vibrio parahaemolyticus, Escherichia coli, Salmonella enterica and Bacillus cereus when used with AgNPs. Elbeshehy et al., 2015 fabricated AgNPs using three strains of Bacillus licheniformis, B. persicus and Bacillus pumilus and tested the antimicrobial activity of these AgNPs against the human pathogens Candida albicans ATCC 1021, Escherichia coli ATCC 25922, Staphylococcus epidermidis ATCC 1228, Aspergillus flavus, Shigella sonnei ATCC25931, Streptococcus bovis ATCC 49147, Pseudomonas aeruginosa, Klebsiella pneumonia ATCC 700603 and Staphylococcus aureus (methicillin-resistant strain) ATCC 43330 [218]. The maximum antimicrobial activity was observed with the AgNPs synthesized using B. licheniformis.

Mahmoud et al., 2016 biosynthesized AgNPs from Bacillus pumilus and studied the antimicrobial activity of these NPs against the pathogenic bacteria S. aureu, S. bovis, S. sonnei, E. coli, S. typhimurium and K. pneumonia [219]. Similarly, Roychoudhury et al., 2016 synthesized AgNPs using the bacterium Lyngbya majuscule (CUH/Al/MW-150) and found that these AgNPs showed effective antibacterial activity against P. aeruginosa. These AgNPs were also observed to act as effective antiproliferative agents against leukemic cells and the REH cell line [42]. Al-Dhabi et al., 2018 observed that AgNPs synthesized from Streptomyces sp. Al-dhabi-87 showed strong antibacterial activity against S. epidermidis, E. faecalis, B. subtilis and the multidrug-resistant $S$. aureus strain [31]. There are many reports available regarding the application of AgNPs as antimicrobial agents. However, only few reports are available regarding the use of other NPs as antibacterial agents. For instance, the strong antibacterial activity of AuNPs extracellularly synthesized from Nocardiopsis sp. MBRC-48 has been reported against C. albicans and S. aureus [50]. Malarkodi et al., 2013 studied the antimicrobial efficacy of titanium oxide NPs (TiO2 NPs) obtained from Planomicrobium sp. against the Gram-negative bacterium K. planticola, Gram-positive bacterium B. subtilis and fungi $A$. Niger. In this study, it was observed that the TiO2NPs exhibited the maximum inhibition against both the bacteria at $0.4 \mathrm{ppm}$ concentration in comparison to the antibiotic Kanamycin, while the fungal growth was maximally inhibited at a $1 \mathrm{~mL}$ concentration of TiO2NPs [220].

There are also reports on the antibacterial activities of zinc oxide NPs against many disease-causing bacteria (Pseudomonas alcaligenes, Proteus mirabilis, Enterobacter aerogenes, Streptococcus pyogenes, Pseudomonas aeruginosa, Salmonella typhimurium, Staphylococcus epidermidis, Proteus vulgaris, Shigella flexneri, Klebsiella pneumonia, Bacillus subtilis and Enterococcus faecalis) [221-223]. In a recent report, Jain et al., 2020 biosynthesized ZnONPs using the zinc-resistant bacterium Serratia nematodiphila and, in vitro, tested the antimicrobial activity of ZnONPs against Xanthomonas oryzaepv. oryzae [224]. Xanthomonas oryzaepv. oryzae is resistant to penicillin, while the ZNONPs clearly inhibited the growth of this bacterium.

\subsection{Role of Nanoparticles in Drug Delivery and Diagnostics}

Currently, cancer, which is characterized by the uncontrolled growth of cells, is one of the most threatening diseases. Traditional methods (chemotherapy, radiation and surgery) for curing cancers are not free from ill effects. Moreover, targeted drug delivery to the affected organ and early diagnostic of this devastating disease is still in its infancy [225]. Therefore, it is crucial to develop certain alternative methods of diagnosis and treatment 
of this disease. It has been reported that nanomedicines can be successfully deployed for the diagnosis of a tumor and its treatment via targeted drug delivery [226]. For example, Borseet al., 2015 studied the in vitro anticancer efficacy of biofabricated PtNPs obtained from Saccharomyces boulardii against MCF-7 and A431 cell lines [227]. Nanomedicines have been used against different types of cancer cell lines. Breast cancer has a high reoccurrence rate in women. Ortega et al., 2015 tested the efficacy of AgNPs biosynthesized from Cryptococcus laurentii and observed that biofabricated AgNPs showed effective anticancerous and antitumor properties against cancer and breast cancer cell lines [140]. Biosynthesized SeNPs also showed anticancer activity. Ahmad et al., 2015 tested biofabricated Se nanorods (SeNrs) from the Streptomyces bikiniensis strain EssamA-1 against human cancer lines and found that these nanorods lead to the mortality of Hep-G2 and MCF-7 cancer cells [47]. Ramya et al., 2015 observed that SeNPs extracellularly fabricated from the bacterium Streptomyces minutiscleroticus M10A62 showed considerable antiproliferative activity against HepG2 and HeLa cell lines [41]. El-Batal et al., 2015, studied the efficacy of AuNPs against human liver (HEPG-2) and breast carcinoma (MCF7) cell lines and observed that AuNPs induce apoptosis of mitochondria, cytokinesis detention, impairment of DNA and degradation of nuclei in cancer cell lines [228]. Thus, there are many reports where NPs have been deployed for their anticancerous role in controlled conditions. However, factors such as toxicity, doses and host immune response during treatment are still required to be addressed prior to their commercialization.

Nanomaterials can be effectively used as a vehicle for targeted drug delivery and are a very useful tool in enhancing the bioavailability, stability and bioactivity of drugs. Major drug delivery nanomaterials include liposomes, nanospheres, polymeric micelles, watersoluble polymers, nano emulsions and NP-coated natural antibodies $[229,230]$. Nanomaterials as drug delivery vehicles have many advantages over traditional methods. Targeted drug delivery can reduce the risk of side-effects caused by the toxicity of drugs in patients. Kundu et al., 2014 studied the efficacy of ZnONPs biofabricated from Rhodococcus pyridinivorans as nanovehicles for anthraquinone [231]. The concentration-dependent cytotoxicity of ZnONPs loaded with anthraquinone was observed against HT-29 colon carcinoma cells, and it was concluded that ZnONPs loaded with anthraquinone could be deployed for targeted drug delivery.

Nanomaterials with hydrophilic properties can increase the absorption of drugs and enhance the cytotoxicity of drugs via better diffusion. Kumar et al., 2008 tested biofabricated AuNPs coupled with the drug doxorubicin against HEK293 cancer cell lines and found that the drug coupled with AuNPs more quickly diffused into HEK293 cancer cell lines [232]. Syed et al., 2013 also observed similar results using AuNPs coupled with the drug doxorubicin against hepatic cancer cells [145]. Khan et al., 2014 demonstrated that the anticancer drug taxol coupled with biosynthesized gadolinium oxide NPs as a drug delivery system could be used effectively in the treatment of cancers [233].

The conventional methods of disease diagnosis are laborious, costly and time consuming. NPs can offer cost effective, fast, specific and accurate detection of pathogens as well as chronic diseases. Nanomaterials, such as magnetic NPs, fluorescent NPs (such as quantum dots and dye-loaded NPs) and metallic NPs can be efficiently used for identification, imaging and tracking of pathogens and disease development [234]. Fluorescent NPs can be used for imaging of the early stage of chronic diseases such as cancer. Magnetic NPs can be used in advance detection techniques such as MRI. For instance, biofabricatedAuNPs from Candida albicans have been used as a probe for liver cancer cells. The AuNPs specifically bound to cancer cells only and facilitated in differentiating cancer cells from normal cells [235]. Thus, microbe-based NPs have a significant role in disease diagnosis; however, their application in detection and diagnosis is still in a developing stage, and rigorous studies are required for their applications in this field. 


\subsection{Application of Nanoparticles in Food Industry}

NPs can be used in the food industry in two important areas, food packaging and food processing [236,237]. For instance, Espitiaet et al., 2012 blended zinc oxide NPs with polymeric material for the synthesis of packaging material. The newly synthesized packaging tissue showed improved antibacterial characteristics [237]. Similarly, other studies also suggested that zinc oxide NPs could be employed for synthesizing containers and nutritional covers for packaging food materials [238,239]. The use of nanomaterials in packaging materials prevents contamination and keeps the food item fresh [2]. AgNPs have a specific capability to pierce the biofilm of bacterial cells, which provides them with resistance against stress. Hence, AgNPs can also be deployed in the decontamination and cleaning process during food packaging [240].

\subsection{Applications of Nanoparticles in Agriculture}

NPs have applications in agriculture as nanofertilizers, nanopesticides and nanoinsecticides [2]. Some of the important applications of NPs in the agriculture sector are discussed below.

\subsubsection{Nanoparticles as Fungicides}

NPs of metal and metal oxides have excellent antifungal properties. Fungi are the most damaging plant pathogens which cause several diseases in plants. In some recent reports, it has been observed that copper and copper oxide NPs biofabricated from Streptomyces spp. showed a good antifungal property against various pathogenic fungi, such as Pythium ultimum, Alternaria alternata, Fusarium oxysporum and Aspergillus niger [121,149]. In another study, Kaur et al., 2018 tested the antifungal activity of biosynthesized AgNPs (synthesized from Pseudomonas sp. and Achromobacter sp.) against Fusarium oxysporum infection in chickpea [241]. In this study, biosynthesized AgNPs were applied in in vivo and in vitro pot experiments, and it was observed that AgNPs exhibited very strong antifungal action against Fusarium oxysporum. Hence, NPs can be effectively used as fungicides for treating fungal diseases in plants. However, the dose of NPs and their toxicity are still major issues for the commercialization of NPs as fungicides.

\subsubsection{Nanoparticles as Fertilizers}

The ever-decreasing soil fertility due to overuse of chemical fertilizers is a major issue in the agricultural sector. NPs can be used for the production of alternative nanofertilizers which are nontoxic, efficient and ecofriendly [2]. In a recent report, Bisinoti et al., 2019 used carbon-based nanomaterials as fertilizers in soil and concluded that the nanomaterial-based fertilizers could reduce the use of chemical fertilizers [242]. In other studies, Guo et al., 2018 elucidated that zeolites and nanoclay minerals or crystals can also be used as fertilizers [243]. Subbarao et al., 2013 demonstrated that the coating of nanomaterial over potash fertilizer resulted in its slow release [244], which can reduce the loss of fertilizer and minimize the overuse of chemical fertilizers [245].

\subsubsection{Nanoparticles as Pesticides}

NPs can also be used for the production of nanopesticides. Nanopesticides may contain NPs in the form of micelles, particles, nanopolymers (organic constituent) and metal oxides (inorganic constituent). In recent years, many new preparations containing NPs have been produced and used as pesticides. It has been explained in many studies that metallic NPs can be used as effective pesticides against various insects and pests, which incur yield losses in agriculture across the globe [246-249]. For instance, Wang et al., 2007 demonstrated that oil-water $(\mathrm{O} / \mathrm{W})$ based novel nanoemulsion could be effectively used as a carrier for the pesticide beta-pypermethrin (beta-PP). This study concluded that beta-PP coated on $\mathrm{O} / \mathrm{W}$ nanoemulsion spread more efficiently than normal beta-PP and reduced the overall use of this pesticide [250]. In another study, Goswami et al., 2010 observed that the diseases caused by the baculovirus Bombyx mori nuclear polyhedrosis virus and 
Sitophilus oryzae in silkworm can be controlled by various NPs, such as zinc oxide, silver, aluminum oxide and titanium oxide NPs [247]. Hence, NPs can be effectively used as pesticides. However, the dose of NPs and their toxicity to plants are still major issues for the commercialization of NPs as pesticides.

\subsubsection{Applications of Nanoparticles in Bioremediation}

The remediation of highly persistent and xenobiotic water pollutants like cationic dyes, acid dyes, azo dyes and other such pollutants is crucial for wastewater treatment and its future use. These pollutants enhance the water pollution and negatively affect aquatic life. NPs have a larger surface area and smaller size and can therefore either act as catalyst or adsorb the pollutants over their larger surface area. In many reports, the catalytic properties of some NPs coupled with biological components have been evaluated for reducing toxic pollutants [251,252]. Sharma et al., 2015 observed that AgNPs efficiently decolorize organic dyes through catalytic activity. They showed that NPs can be used as a catalyst in industries for the degradation of organic dyes with high efficiency [253]. It has been reported that both Ag and AuNPs exhibit acceptable catalytic activity in the removal of organic dyes. These NPs decrease the time required for the removal of dye and efficiently enhance the rate of reaction [254,255]. Bhargava et al., 2016 demonstrated that AuNPs can also be used as an adsorbent for organic dyes. It was observed that AuNPs having surface proteins synthesized from fungus Cladosporium oxysporum AJP03 efficiently improved the adsorption of rhodamine-B organic dye [152]. Recently, Koul and Taak (2018) described the roles of $\mathrm{TiO}_{2} \mathrm{NPs}$, FeNPs, bimetallic NPs, magnetic NPs, nanoclays, nanotubes and nanosponges in soil bioremediation. The authors emphasized that the green synthesis of NPs could be an effective way to treat soil and water pollution [256].

\section{Future Perspectives and Conclusions}

Microbial cells are fast growing, easy to maintain and can be used for the safer and rapid production of NPs of a desired nature and structure. However, the biosynthesis of NPs via microbial synthesis has many drawbacks, which may include achieving a homogenous shape, symmetry, composition and size of NPs which is governed by environmental conditions, such as temperature and $\mathrm{pH}$ of the medium [71]. Although recent studies have shown the huge potential of microbes for the synthesis of novel NPs and their use in biomedicines and cancer treatment [257-259], the methods of biosynthesis using microbes need to be modified for commercial production, and the synthesis of NPs needs to be scaled up compared to traditional methods. Moreover, an in-depth investigation is required to study the toxicity, biocompatibility and potential effect of NPs on the immune system, respiratory system, hepatobiliary system, reproductive system, kidney, eyes, skin and other organs [260]. The use of genetically engineered microorganisms for the fabrication of NPs of a desired shape and size is novel in this arena. Genetically engineered organisms have several advantages over the conventional bioproduction of nanomaterials, such as the rate of biosynthesis, cost of production and energy efficiency. Although the biofabrication of NPs using genetically engineered organisms has many advantages, such as environmental safety, cost effectiveness and feasibility of NP production, the use of recombinant organisms is still very scarce. Issues like reproducibility, purity and separation of NPs and the survival of recombinant strains are still required to be addressed to improve NP synthesis using genetically engineered organisms. Moreover, researchers also face challenges related to public acceptance, biosafety, biosecurity and transgene escape when using genetically engineered organisms for the fabrication of NPs [75]. However, it is expected that in the near future, the biofabrication of NPs using genetically engineered organisms will receive significant attention and will be a method of choice for the sustainable production of nanomaterials. Thus, NPs have immense potential in different applications. However, factors such as toxicity, doses and host immune response during treatment are still required to be addressed prior to the commercialization of NPs. 
Author Contributions: A.K.P. and B.K. wrote the first draft of the manuscript. The final draft was read and edited by B.K., D.Y. and J.-O.J. All authors listed have made a substantial, direct and intellectual contribution to the work and approved it for publication. All authors have read and agreed to the published version of the manuscript.

Funding: This work was supported by the National Research Foundation of Korea (NRF) funded by the Ministry of Education (NRF-2019R1G1A1008566, NRF-2019R1C1C1003334 and NRF2020R1A6A1A03044512).

Acknowledgments: The authors are thankful to Lovely Professional University (LPU), Punjab, India, and the Centre for Plant Biotechnology, CCSHAU, Haryana, India, for infrastructural support.

Conflicts of Interest: The authors declare that the research was conducted in the absence of any commercial or financial relationships that could be construed as a potential conflict of interest.

\section{References}

1. Elfeky, A.S.; Salem, S.S.; Elzaref, A.S.; Owda, M.E.; Eladawy, H.A.; Saeed, A.M.; Awad, M.A.; Abou-Zeid, R.E.; Fouda, A. Multifunctional cellulose nanocrystal / metal oxide hybrid, photo-degradation, antibacterial and larvicidal activities. Carbohydr. Polym. 2020, 230, 115711. [CrossRef] [PubMed]

2. Salem, S.S.; Fouda, A. Green synthesis of metallic nanoparticles and their prospective biotechnological applications: An overview. Biol. Trace Elem. Res. 2021, 199, 344-370. [CrossRef] [PubMed]

3. Khan, I.; Saeed, K.; Khan, I. Nanoparticles: Properties, applications and toxicities. Arab. J. Chem. 2019, 12, 908-931. [CrossRef]

4. Gahlawat, G.; Choudhury, A.R. A review on the biosynthesis of metal and metal salt nanoparticles by microbes. RSC Adv. 2019, 9 , 12944-12967. [CrossRef]

5. Grasso, G.; Zane, D.; Dragone, R. Microbial nanotechnology: Challenges and prospects for green biocatalytic synthesis of nanoscale materials for sensoristic and biomedical applications. Nanomaterials 2020, 10, 11. [CrossRef]

6. Inshakova, E.; Inshakov, O. World market for nanomaterials: Structure and trends. In Proceedings of the MATEC Web of Conferences, Sevastopol, Russia, 11-15 September 2017; EDP Sciences: Les Ulis, France, 2017; Volume 129, p. 02013.

7. Dobias, J.; Suvorova, E.I.; Bernier-Latmani, R. Role of proteins in controlling selenium nanoparticle size. Nanotechnology 2011, 22, 195605. [CrossRef]

8. Shedbalkar, U.; Singh, R.; Wadhwani, S.; Gaidhani, S.; Chopade, B. Microbial synthesis of gold nanoparticles: Current status and future prospects. Adv. Colloid Interface Sci. 2014, 209, 40-48. [CrossRef]

9. Albanese, A.; Tang, P.S.; Chan, W.C. The effect of nanoparticle size, shape, and surface chemistry on biological systems. Annu. Rev. Biomed. Eng. 2012, 14, 1-16. [CrossRef]

10. Arshad, A.; Iqbal, J.; Mansoor, Q.; Ahmed, I. Graphene/sio2 nanocomposites: The enhancement of photocatalytic and biomedical activity of sio2 nanoparticles by graphene. J. Appl. Phys. 2017, 121, 244901. [CrossRef]

11. Nath, D.; Banerjee, P. Green nanotechnology-A new hope for medical biology. Environ. Toxicol. Pharmacol. 2013, 36, 997-1014. [CrossRef]

12. Kharisov, B.I.; Kharissova, O.V.; Ortiz Mendez, U.; De La Fuente, I.G. Decoration of carbon nanotubes with metal nanoparticles: Recent trends. Synth. React. Inorg. Met. Chem. 2016, 46, 55-76. [CrossRef]

13. You, H.; Yang, S.; Ding, B.; Yang, H. Synthesis of colloidal metal and metal alloy nanoparticles for electrochemical energy applications. Chem. Soc. Rev. 2013, 42, 2880-2904. [CrossRef]

14. Shah, M.; Fawcett, D.; Sharma, S.; Tripathy, S.K.; Poinern, G.E.J. Green synthesis of metallic nanoparticles via biological entities. Materials 2015, 8, 7278-7308. [CrossRef]

15. Fariq, A.; Khan, T.; Yasmin, A. Microbial synthesis of nanoparticles and their potential applications in biomedicine. J. Appl. Biomed. 2017, 15, 241-248. [CrossRef]

16. Castro, L.; Blázquez, M.L.; González, F.G.; Ballester, A. Mechanism and applications of metal nanoparticles prepared by bio-mediated process. Rev. Adv. Sci. Eng. 2014, 3, 199-216. [CrossRef]

17. Jang, H.D.; Kim, S.K.; Chang, H.; Choi, J.-H.; Cho, B.-G.; Jo, E.H.; Choi, J.-W.; Huang, J. Three-dimensional crumpled graphenebased platinum-gold alloy nanoparticle composites as superior electrocatalysts for direct methanol fuel cells. Carbon 2015, 93, 869-877. [CrossRef]

18. Singh, P.; Kim, Y.-J.; Zhang, D.; Yang, D.-C. Biological synthesis of nanoparticles from plants and microorganisms. Trends Biotechnol. 2016, 34, 588-599. [CrossRef]

19. Saravanan, M.; Barik, S.K.; MubarakAli, D.; Prakash, P.; Pugazhendhi, A. Synthesis of silver nanoparticles from bacillus brevis (ncim 2533) and their antibacterial activity against pathogenic bacteria. Microb. Pathog. 2018, 116, 221-226. [CrossRef]

20. Buszewski, B.; Railean-Plugaru, V.; Pomastowski, P.; Rafińska, K.; Szultka-Mlynska, M.; Golinska, P.; Wypij, M.; Laskowski, D.; Dahm, H. Antimicrobial activity of biosilver nanoparticles produced by a novel streptacidiphilus durhamensis strain. J. Microbiol. Immunol. Infect. 2018, 51, 45-54. [CrossRef]

21. Sanaeimehr, Z.; Javadi, I.; Namvar, F. Antiangiogenic and antiapoptotic effects of green-synthesized zinc oxide nanoparticles using sargassum muticum algae extraction. Cancer Nanotechnol. 2018, 9, 1-16. [CrossRef] 
22. He, S.; Zhang, Y.; Guo, Z.; Gu, N. Biological synthesis of gold nanowires using extract of rhodopseudomonas capsulata. Biotechnol. Prog. 2008, 24, 476-480. [CrossRef] [PubMed]

23. Li, C.; Zhou, L.; Yang, H.; Lv, R.; Tian, P.; Li, X.; Zhang, Y.; Chen, Z.; Lin, F. Self-assembled exopolysaccharide nanoparticles for bioremediation and green synthesis of noble metal nanoparticles. ACS Appl. Mater. Interfaces 2017, 9, 22808-22818. [CrossRef] [PubMed]

24. Golmohammadi, H.; Morales-Narvaez, E.; Naghdi, T.; Merkoci, A. Nanocellulose in sensing and biosensing. Chem. Mater. 2017, 29, 5426-5446. [CrossRef]

25. Shivaji, S.; Madhu, S.; Singh, S. Extracellular synthesis of antibacterial silver nanoparticles using psychrophilic bacteria. Process. Biochem. 2011, 46, 1800-1807. [CrossRef]

26. Kang, S.H.; Bozhilov, K.N.; Myung, N.V.; Mulchandani, A.; Chen, W. Microbial synthesis of cds nanocrystals in genetically engineered E. Coli. Angew. Chem. 2008, 120, 5264-5267. [CrossRef]

27. Chan, W.C.W. Nano research for COVID-19. ACS Nano 2020, 14, 3719-3720. [CrossRef] [PubMed]

28. Li, X.; Xu, H.; Chen, Z.-S.; Chen, G. Biosynthesis of Nanoparticles by Microorganisms and Their Applications. J. Nanomater. 2011, 2011, 1-16. [CrossRef]

29. Das, V.L.; Thomas, R.; Varghese, R.T.; Soniya, E.; Mathew, J.; Radhakrishnan, E. Extracellular synthesis of silver nanoparticles by the bacillus strain cs 11 isolated from industrialized area. 3 Biotech 2014, 4, 121-126. [CrossRef]

30. Yadav, A.; Kon, K.; Kratosova, G.; Duran, N.; Ingle, A.P.; Rai, M. Fungi as an efficient mycosystem for the synthesis of metal nanoparticles: Progress and key aspects of research. Biotechnol. Lett. 2015, 37, 2099-2120. [CrossRef]

31. Al-Dhabi, N.A.; Mohammed Ghilan, A.-K.; Arasu, M.V. Characterization of silver nanomaterials derived from marine streptomyces sp. Al-dhabi-87 and its in vitro application against multidrug resistant and extended-spectrum beta-lactamase clinical pathogens. Nanomaterials 2018, 8, 279. [CrossRef]

32. Marooufpour, N.; Alizadeh, M.; Hatami, M.; Lajayer, B.A. Biological Synthesis of Nanoparticles by Different Groups of Bacteria. In Microbial Nanobionics; Springer: Cham, Switzerland, 2019; pp. 63-85.

33. Jeevan, P.; Ramya, K.; Rena, A.E. Extracellular biosynthesis of silver nanoparticles by culture supernatant of pseudomonas aeruginosa. Indian J. Biotechnol. 2012, 11, 72-76.

34. Fernández-Llamosas, H.; Castro, L.; Blázquez, M.L.; Díaz, E.; Carmona, M. Speeding up bioproduction of selenium nanoparticles by using vibrio natriegens as microbial factory. Sci. Rep. 2017, 7, 16046. [CrossRef]

35. Waghmare, S.R.; Mulla, M.N.; Marathe, S.R.; Sonawane, K.D. Ecofriendly production of silver nanoparticles using candida utilis and its mechanistic action against pathogenic microorganisms. 3 Biotech 2015, 5, 33-38. [CrossRef]

36. Kalabegishvili, T.L.; Kirkesali, E.I.; Rcheulishvili, A.N.; Ginturi, E.N.; Murusidze, I.G.; Pataraya, D.T.; Gurielidze, M.A.; Tsertsvadze, G.I.; Gabunia, V.N.; Lomidze, L.G. Synthesis of gold nanoparticles by some strains of arthrobacter genera. J. Mater. Sci. Eng. A Struct. Mater. Prop. Microstruct. Process. 2012, 2, 164-173.

37. Du, L.; Jiang, H.; Liu, X.; Wang, E. Biosynthesis of gold nanoparticles assisted by escherichia coli dh $5 \alpha$ and its application on direct electrochemistry of hemoglobin. Electrochem. Commun. 2007, 9, 1165-1170. [CrossRef]

38. Suresh, A.K.; Pelletier, D.A.; Wang, W.; Broich, M.L.; Moon, J.W.; Gu, B.; Allison, D.P.; Joy, D.C.; Phelps, T.J.; Doktycz, M.J. Biofabrication of discrete spherical gold nanoparticles using the metal-reducing bacterium shewanella oneidensis. Acta Biomater. 2011, 7, 2148-2152. [CrossRef]

39. Bao, H.; Lu, Z.; Cui, X.; Qiao, Y.; Guo, J.; Anderson, J.M.; Li, C.M. Extracellular microbial synthesis of biocompatible cdte quantum dots. Acta Biomater. 2010, 6, 3534-3541. [CrossRef]

40. Wang, T.; Yang, L.; Zhang, B.; Liu, J. Extracellular biosynthesis and transformation of selenium nanoparticles and application in h2o2 biosensor. Colloids Surf. B Biointerfaces 2010, 80, 94-102. [CrossRef]

41. Ramya, S.; Shanmugasundaram, T.; Balagurunathan, R. Biomedical potential of actinobacterially synthesized selenium nanoparticles with special reference to anti-biofilm, anti-oxidant, wound healing, cytotoxic and anti-viral activities. J. Trace Elem. Med. Biol. 2015, 32, 30-39. [CrossRef] [PubMed]

42. Roychoudhury, P.; Gopal, P.K.; Paul, S.; Pal, R. Cyanobacteria assisted biosynthesis of silver nanoparticles-A potential antileukemic agent. J. Appl. Phycol. 2016, 28, 3387-3394. [CrossRef]

43. Shao, W.; Liu, H.; Liu, X.; Sun, H.; Wang, S.; Zhang, R. Ph-responsive release behavior and anti-bacterial activity of bacterial cellulose-silver nanocomposites. Int. J. Biol. Macromol. 2015, 76, 209-217. [CrossRef] [PubMed]

44. Torres, S.; Campos, V.; León, C.; Rodríguez-Llamazares, S.; Rojas, S.; Gonzalez, M.; Smith, C.; Mondaca, M. Biosynthesis of selenium nanoparticles by pantoea agglomerans and their antioxidant activity. J. Nanopart. Res. 2012, 14, 1236. [CrossRef]

45. Kalishwaralal, K.; Banumathi, E.; Pandian, S.R.K.; Deepak, V.; Muniyandi, J.; Eom, S.H.; Gurunathan, S. Silver nanoparticles inhibit vegf induced cell proliferation and migration in bovine retinal endothelial cells. Colloids Surf. B Biointerfaces 2009, 73, 51-57. [CrossRef] [PubMed]

46. Kalishwaralal, K.; Deepak, V.; Pandian, S.R.K.; Kottaisamy, M.; BarathManiKanth, S.; Kartikeyan, B.; Gurunathan, S. Biosynthesis of silver and gold nanoparticles using brevibacterium casei. Colloids Surf. B Biointerfaces 2010, 77, 257-262. [CrossRef]

47. Ahmad, M.S.; Yasser, M.M.; Sholkamy, E.N.; Ali, A.M.; Mehanni, M.M. Anticancer activity of biostabilized selenium nanorods synthesized by streptomyces bikiniensis strain ess_ama-1. Int. J. Nanomed. 2015, 10, 3389.

48. Gurunathan, S.; Han, J.W.; Eppakayala, V.; Kim, J.-H. Green synthesis of graphene and its cytotoxic effects in human breast cancer cells. Int. J. Nanomed. 2013, 8, 1015. [CrossRef] 
49. Suresh, A.K.; Pelletier, D.A.; Wang, W.; Moon, J.-W.; Gu, B.; Mortensen, N.P.; Allison, D.P.; Joy, D.C.; Phelps, T.J.; Doktycz, M.J. Silver nanocrystallites: Biofabrication using shewanella oneidensis, and an evaluation of their comparative toxicity on gram-negative and gram-positive bacteria. Environ. Sci. Technol. 2010, 44, 5210-5215. [CrossRef]

50. Manivasagan, P.; Alam, M.S.; Kang, K.-H.; Kwak, M.; Kim, S.-K. Extracellular synthesis of gold bionanoparticles by nocardiopsis sp. And evaluation of its antimicrobial, antioxidant and cytotoxic activities. Bioprocess Biosyst. Eng. 2015, 38, 1167-1177. [CrossRef]

51. Mondal, A.H.; Yadav, D.; Ali, A.; Khan, N.; Jin, J.O.; Haq, Q.M.R. Anti-bacterial and anti-candidal activity of silver nanoparticles biosynthesized using citrobacter spp. Ms5 culture supernatant. Biomolecules 2020, 10, 944. [CrossRef]

52. Mondal, A.H.; Yadav, D.; Mitra, S.; Mukhopadhyay, K. Biosynthesis of silver nanoparticles using culture supernatant of shewanella sp. Ary1 and their antibacterial activity. Int. J. Nanomed. 2020, 15, 8295-8310. [CrossRef]

53. Morones, J.R.; Elechiguerra, J.L.; Camacho, A.; Holt, K.; Kouri, J.B.; Ramírez, J.T.; Yacaman, M.J. The bactericidal effect of silver nanoparticles. Nanotechnology 2005, 16, 2346-2353. [CrossRef]

54. Bridges, K.; Kidson, A.; Lowbury, E.; Wilkins, M. Gentamicin-and silver-resistant pseudomonas in a burns unit. Br. Med. J. 1979, 1, 446-449. [CrossRef]

55. Haefeli, C.; Franklin, C.; Hardy, K.E. Plasmid-determined silver resistance in pseudomonas stutzeri isolated from a silver mine. J. Bacteriol. 1984, 158, 389-392. [CrossRef]

56. NVKV Prasad, T.; Subba Rao Kambala, V.; Naidu, R. A critical review on biogenic silver nanoparticles and their antimicrobial activity. Curr. Nanosci. 2011, 7, 531-544. [CrossRef]

57. Iravani, S. Bacteria in nanoparticle synthesis: Current status and future prospects. Int. Sch. Res. Not. 2014, 2014, 359316. [CrossRef]

58. Klaus, T.; Joerger, R.; Olsson, E.; Granqvist, C.-G. Silver-based crystalline nanoparticles, microbially fabricated. Proc. Natl. Acad. Sci. USA 1999, 96, 13611-13614. [CrossRef]

59. Nair, B.; Pradeep, T. Coalescence of nanoclusters and formation of submicron crystallites assisted by lactobacillus strains. Cryst. Growth Des. 2002, 2, 293-298. [CrossRef]

60. Shahverdi, A.R.; Minaeian, S.; Shahverdi, H.R.; Jamalifar, H.; Nohi, A.-A. Rapid synthesis of silver nanoparticles using culture supernatants of enterobacteria: A novel biological approach. Process Biochem. 2007, 42, 919-923. [CrossRef]

61. Shahverdi, A.R.; Fakhimi, A.; Shahverdi, H.R.; Minaian, S. Synthesis and effect of silver nanoparticles on the antibacterial activity of different antibiotics against staphylococcus aureus and escherichia coli. Nanomedicine 2007, 3, 168-171. [CrossRef] [PubMed]

62. Kalimuthu, K.; Suresh Babu, R.; Venkataraman, D.; Bilal, M.; Gurunathan, S. Biosynthesis of silver nanocrystals by bacillus licheniformis. Colloids Surf. B Biointerfaces 2008, 65, 150-153. [CrossRef]

63. Parikh, R.Y.; Singh, S.; Prasad, B.L.; Patole, M.S.; Sastry, M.; Shouche, Y.S. Extracellular synthesis of crystalline silver nanoparticles and molecular evidence of silver resistance from morganella sp.: Towards understanding biochemical synthesis mechanism. Chembiochem 2008, 9, 1415-1422. [CrossRef] [PubMed]

64. Mokhtari, N.; Daneshpajouh, S.; Seyedbagheri, S.; Atashdehghan, R.; Abdi, K.; Sarkar, S.; Minaian, S.; Shahverdi, H.R.; Shahverdi, A.R. Biological synthesis of very small silver nanoparticles by culture supernatant of klebsiella pneumonia: The effects of visible-light irradiation and the liquid mixing process. Mater. Res. Bull. 2009, 44, 1415-1421. [CrossRef]

65. Nanda, A.; Saravanan, M. Biosynthesis of silver nanoparticles from staphylococcus aureus and its antimicrobial activity against mrsa and mrse. Nanomedicine 2009, 5, 452-456. [CrossRef] [PubMed]

66. Ramanathan, R.; O'Mullane, A.P.; Parikh, R.Y.; Smooker, P.M.; Bhargava, S.K.; Bansal, V. Bacterial kinetics-controlled shapedirected biosynthesis of silver nanoplates using morganella psychrotolerans. Langmuir 2011, 27, 714-719. [CrossRef]

67. Prakash, A.; Sharma, S.; Ahmad, N.; Ghosh, A.; Sinha, P. Synthesis of agnps by bacillus cereus bacteria and their antimicrobial potential. J. Biomater. Nanobiotechnol. 2011, 2, 155. [CrossRef]

68. Sunkar, S.; Nachiyar, C.V. Biogenesis of antibacterial silver nanoparticles using the endophytic bacterium bacillus cereus isolated from garcinia xanthochymus. Asian Pac. J. Trop. Biomed. 2012, 2, 953-959. [CrossRef]

69. Lin, Z.-Y.; Fu, J.-K.; Wu, J.-M.; Liu, Y.-Y.; Cheng, H. Preliminary study on the mechanism of non-enzymatic bioreduction of precious metal ions. Acta Phys. Chim. Sin. 2001, 17, 477-480. [CrossRef]

70. Yong, P.; Rowson, N.A.; Farr, J.P.G.; Harris, I.R.; Macaskie, L.E. Bioreduction and biocrystallization of palladium by desulfovibrio desulfuricans ncimb 8307. Biotechnol. Bioeng. 2002, 80, 369-379. [CrossRef]

71. Hulkoti, N.I.; Taranath, T. Biosynthesis of nanoparticles using microbes-A review. Colloids Surf. B Biointerfaces 2014, 121, 474-483. [CrossRef]

72. Zhang, D.; Ma, X.-L.; Gu, Y.; Huang, H.; Zhang, G.-W. Green synthesis of metallic nanoparticles and their potential applications to treat cancer. Front. Chem. 2020, 8, 799. [CrossRef]

73. Kulkarni, R.R.; Shaiwale, N.S.; Deobagkar, D.N.; Deobagkar, D.D. Synthesis and extracellular accumulation of silver nanoparticles by employing radiation-resistant deinococcus radiodurans, their characterization, and determination of bioactivity. Int. J. Nanomed. 2015, 10, 963.

74. Yumei, L.; Yamei, L.; Qiang, L.; Jie, B. Rapid biosynthesis of silver nanoparticles based on flocculation and reduction of an exopolysaccharide from arthrobacter sp. B4: Its antimicrobial activity and phytotoxicity. J. Nanomater. 2017, 2017, 9703614. [CrossRef]

75. Iravani, S.; Varma, R.S. Biofactories: Engineered nanoparticles via genetically engineered organisms. Green Chem. 2019, 21, 4583-4603. [CrossRef] 
76. Wing-ShanáLin, I. Biosynthesis of silver nanoparticles from silver (i) reduction by the periplasmic nitrate reductase c-type cytochrome subunit napc in a silver-resistant e. Ácoli. Chem. Sci. 2014, 5, 3144-3150.

77. Ramanathan, R.; Field, M.R.; O’Mullane, A.P.; Smooker, P.M.; Bhargava, S.K.; Bansal, V. Aqueous phase synthesis of copper nanoparticles: A link between heavy metal resistance and nanoparticle synthesis ability in bacterial systems. Nanoscale 2013, 5, 2300-2306. [CrossRef]

78. Yuan, Q.; Bomma, M.; Xiao, Z. Enhanced silver nanoparticle synthesis by escherichia coli transformed with candida albicans metallothionein gene. Materials 2019, 12, 4180. [CrossRef]

79. Fu, J.-Z.; Liu, Y.-Y.; Gu, P.-Y.; Shang, D.-L.; Lin, Z.-Y.; Yao, B.-X.; Weng, S.-Z. Spectroscopic charcterization on the biosorption and bioreduction of ag(i) by lactobacillus sp.A09*. Acta Phys. -Chim. Sin. 2000, 16, 779-782. [CrossRef]

80. Ahmad, A.; Mukherjee, P.; Senapati, S.; Mandal, D.; Khan, M.I.; Kumar, R.; Sastry, M. Extracellular biosynthesis of silver nanoparticles using the fungus fusarium oxysporum. Colloids Surf. B Biointerfaces 2003, 28, 313-318. [CrossRef]

81. Lengke, M.F.; Fleet, M.E.; Southam, G. Biosynthesis of silver nanoparticles by filamentous cyanobacteria from a silver(i) nitrate complex. Langmuir 2007, 23, 2694-2699. [CrossRef]

82. Whiteley, C.; Govender, Y.; Riddin, T.; Rai, M. Enzymatic Synthesis of Platinum Nanoparticles: Prokaryote and Eukaryote systems. In Metal Nanoparticles in Microbiology; Springer: Berlin/Heidelberg, Germany, 2011; pp. 103-134.

83. Beveridge, T.; Murray, R. Sites of metal deposition in the cell wall of bacillus subtilis. J. Bacteriol. 1980, 141, 876-887. [CrossRef]

84. Konishi, Y.; Ohno, K.; Saitoh, N.; Nomura, T.; Nagamine, S. Microbial synthesis of gold nanoparticles by metal reducing bacterium. Trans. Mater. Res. Soc. Jpn. 2004, 29, 2341-2343.

85. Husseiny, M.; Abd El-Aziz, M.; Badr, Y.; Mahmoud, M. Biosynthesis of gold nanoparticles using pseudomonas aeruginosa. Spectrochim. Acta Part A Mol. Biomol. Spectrosc. 2007, 67, 1003-1006. [CrossRef] [PubMed]

86. Sneha, K.; Sathishkumar, M.; Mao, J.; Kwak, I.; Yun, Y.-S. Corynebacterium glutamicum-mediated crystallization of silver ions through sorption and reduction processes. Chem. Eng. J. 2010, 162, 989-996. [CrossRef]

87. Liu, C.-J.; Wang, C.-H.; Chen, S.-T.; Chen, H.-H.; Leng, W.-H.; Chien, C.-C.; Wang, C.-L.; Kempson, I.M.; Hwu, Y.; Lai, T.-C. Enhancement of cell radiation sensitivity by pegylated gold nanoparticles. Phys. Med. Biol. 2010, 55, 931. [CrossRef] [PubMed]

88. Correa-Llantén, D.N.; Muñoz-Ibacache, S.A.; Castro, M.E.; Muñoz, P.A.; Blamey, J.M. Gold nanoparticles synthesized by geobacillus sp. Strain id17 a thermophilic bacterium isolated from deception island, antarctica. Microb. Cell Fact. 2013, 12, 75 . [CrossRef]

89. Srinath, B.; Namratha, K.; Byrappa, K. Eco-friendly synthesis of gold nanoparticles by bacillus subtilis and their environmental applications. Adv. Sci. Lett. 2018, 24, 5942-5946. [CrossRef]

90. Lengke, M.F.; Fleet, M.E.; Southam, G. Morphology of gold nanoparticles synthesized by filamentous cyanobacteria from gold(i) - thiosulfate and gold(iii) - chloride complexes. Langmuir 2006, 22, 2780-2787. [CrossRef] [PubMed]

91. Brayner, R.; Barberousse, H.; Hemadi, M.; Djedjat, C.; Yéprémian, C.; Coradin, T.; Livage, J.; Fiévet, F.; Couté, A. Cyanobacteria as bioreactors for the synthesis of au, ag, pd, and pt nanoparticles via an enzyme-mediated route. J. Nanosci. Nanotechnol. 2007, 7 , 2696-2708. [CrossRef]

92. Govindaraju, K.; Basha, S.K.; Kumar, V.G.; Singaravelu, G. Silver, gold and bimetallic nanoparticles production using single-cell protein (spirulina platensis) geitler. J. Mater. Sci. 2008, 43, 5115-5122. [CrossRef]

93. Attaran, N.; Eshghi, H.; Rahimizadeh, M.; Mashreghi, M.; Bakavoli, M. Genetically modified luminescent bacteria ralostonia solanacerum, pseudomonas syringae, pseudomonas savastanoi, and wild type bacterium vibrio fischeri in biosynthesis of gold nanoparticles from gold chloride trihydrate. Artif. Cells Nanomed. Biotechnol. 2016, 44, 263-269. [CrossRef]

94. Brock, T.D.; Gustafson, J. Ferric iron reduction by sulfur- and iron-oxidizing bacteria. Appl. Environ. Microbiol. 1976, 32, 567-571. [CrossRef] [PubMed]

95. Taylor, D.E. Bacterial tellurite resistance. Trends Microbiol. 1999, 7, 111-115. [CrossRef]

96. Lloyd, J.R.; Ridley, J.; Khizniak, T.; Lyalikova, N.N.; Macaskie, L.E. Reduction of technetium by desulfovibrio desulfuricans: Biocatalyst characterization and use in a flowthrough bioreactor. Appl. Environ. Microbiol. 1999, 65, 2691-2696. [CrossRef] [PubMed]

97. Lovley, D.R.; Stolz, J.F.; Nord, G.L.; Phillips, E.J. Anaerobic production of magnetite by a dissimilatory iron-reducing microorganism. Nature 1987, 330, 252-254. [CrossRef]

98. Mullen, M.; Wolf, D.; Ferris, F.; Beveridge, T.; Flemming, C.; Bailey, G. Bacterial sorption of heavy metals. Appl. Environ. Microbiol. 1989, 55, 3143-3149. [CrossRef]

99. Watson, J.; Ellwood, D.; Soper, A.; Charnock, J. Nanosized strongly-magnetic bacterially-produced iron sulfide materials. J. Magn. Magn. Mater. 1999, 203, 69-72. [CrossRef]

100. Bharde, A.; Wani, A.; Shouche, Y.; Joy, P.A.; Prasad, B.L.V.; Sastry, M. Bacterial aerobic synthesis of nanocrystalline magnetite. J. Am. Chem. Soc. 2005, 127, 9326-9327. [CrossRef]

101. Prasad, K.; Jha, A.K.; Kulkarni, A. Lactobacillus assisted synthesis of titanium nanoparticles. Nanoscale Res. Lett. 2007, 2, 248-250. [CrossRef]

102. Cunningham, D.P.; Lundie, L. Precipitation of cadmium by clostridium thermoaceticum. Appl. Environ. Microbiol. 1993, 59, 7-14. [CrossRef]

103. Sweeney, R.Y.; Mao, C.; Gao, X.; Burt, J.L.; Belcher, A.M.; Georgiou, G.; Iverson, B.L. Bacterial biosynthesis of cadmium sulfide nanocrystals. Chem. Biol. 2004, 11, 1553-1559. [CrossRef] 
104. Varshney, R.; Bhadauria, S.; Gaur, M.; Pasricha, R. Copper nanoparticles synthesis from electroplating industry effluent. Nano Biomed. Eng. 2011, 3, 115-119. [CrossRef]

105. Visha, P.; Nanjappan, K.; Selvaraj, P.; Jayachandran, S.; Elango, A.; Kumaresan, G. Biosynthesis and structural characteristics of selenium nanoparticles using lactobacillus acidophilus bacteria by wet sterilization process. Int. J. Adv. Vet. Sci. Technol. 2015, 4, 178-183.

106. Yan, L.; Da, H.; Zhang, S.; López, V.M.; Wang, W. Bacterial magnetosome and its potential application. Microbiol. Res. 2017, 203, 19-28. [CrossRef]

107. Vargas, G.; Cypriano, J.; Correa, T.; Leão, P.; Bazylinski, D.A.; Abreu, F. Applications of magnetotactic bacteria, magnetosomes and magnetosome crystals in biotechnology and nanotechnology: Mini-review. Molecules 2018, 23, 2438. [CrossRef]

108. Alphandery, E.; Faure, S.; Seksek, O.; Guyot, F.; Chebbi, I. Chains of magnetosomes extracted from amb-1 magnetotactic bacteria for application in alternative magnetic field cancer therapy. ACS Nano 2011, 5, 6279-6296. [CrossRef]

109. Roda, A.; Cevenini, L.; Borg, S.; Michelini, E.; Calabretta, M.M.; Schüler, D. Bioengineered bioluminescent magnetotactic bacteria as a powerful tool for chip-based whole-cell biosensors. Lab Chip. 2013, 13, 4881-4889. [CrossRef]

110. Boucher, M.; Geffroy, F.; Prévéral, S.; Bellanger, L.; Selingue, E.; Adryanczyk-Perrier, G.; Pean, M.; Lefèvre, C.; Pignol, D.; Ginet, N. Genetically tailored magnetosomes used as mri probe for molecular imaging of brain tumor. Biomaterials 2017, 121, 167-178. [CrossRef]

111. Zonaro, E.; Piacenza, E.; Presentato, A.; Monti, F.; Dell'Anna, R.; Lampis, S.; Vallini, G. Ochrobactrum sp. Mpv1 from a dump of roasted pyrites can be exploited as bacterial catalyst for the biogenesis of selenium and tellurium nanoparticles. Microb. Cell Fact. 2017, 16, 215. [CrossRef]

112. Ahmed, E.; Kalathil, S.; Shi, L.; Alharbi, O.; Wang, P. Synthesis of ultra-small platinum, palladium and gold nanoparticles by shewanella loihica pv-4 electrochemically active biofilms and their enhanced catalytic activities. J. Saudi Chem. Soc. 2018, 22, 919-929. [CrossRef]

113. Chen, Y.L.; Tuan, H.Y.; Tien, C.W.; Lo, W.H.; Liang, H.C.; Hu, Y.C. Augmented biosynthesis of cadmium sulfide nanoparticles by genetically engineered escherichia coli. Biotechnol. Prog. 2009, 25, 1260-1266. [CrossRef]

114. Jung, J.H.; Park, T.J.; Lee, S.Y.; Seo, T.S. Homogeneous biogenic paramagnetic nanoparticle synthesis based on a microfluidic droplet generator. Angew. Chem. Int. Ed. 2012, 51, 5634-5637. [CrossRef]

115. Kolinko, I.; Lohße, A.; Borg, S.; Raschdorf, O.; Jogler, C.; Tu, Q.; Pósfai, M.; Tompa, E.; Plitzko, J.M.; Brachmann, A. Biosynthesis of magnetic nanostructures in a foreign organism by transfer of bacterial magnetosome gene clusters. Nat. Nanotechnol. 2014, 9 , 193-197. [CrossRef]

116. Choi, Y.; Park, T.J.; Lee, D.C.; Lee, S.Y. Recombinant escherichia coli as a biofactory for various single-and multi-element nanomaterials. Proc. Natl. Acad. Sci. USA 2018, 115, 5944-5949. [CrossRef]

117. Dhoondia, Z.H.; Chakraborty, H. Lactobacillus mediated synthesis of silver oxide nanoparticles. Nanomater. Nanotechnol. 2012, 2, 15. [CrossRef]

118. Li, R.; Chen, Z.; Ren, N.; Wang, Y.; Wang, Y.; Yu, F. Biosynthesis of silver oxide nanoparticles and their photocatalytic and antimicrobial activity evaluation for wound healing applications in nursing care. J. Photochem. Photobiol. B Biol. 2019, 199, 111593. [CrossRef]

119. Vithiya, K.; Kumar, R.; Sen, S. Antimicrobial activity of biosynthesized silver oxide nanoparticles. J. Pure Appl. Microbiol 2014, 4, 3263-3268.

120. Murthy, S.K. Nanoparticles in modern medicine: State of the art and future challenges. Int. J. Nanomed. $2007,2,129$.

121. Hassan, S.E.-D.; Fouda, A.; Radwan, A.A.; Salem, S.S.; Barghoth, M.G.; Awad, M.A.; Abdo, A.M.; El-Gamal, M.S. Endophytic actinomycetes streptomyces spp mediated biosynthesis of copper oxide nanoparticles as a promising tool for biotechnological applications. JBIC J. Biol. Inorg. Chem. 2019, 24, 377-393. [CrossRef]

122. Bukhari, S.I.; Hamed, M.M.; Al-Agamy, M.H.; Gazwi, H.S.; Radwan, H.H.; Youssif, A.M. Biosynthesis of copper oxide nanoparticles using streptomyces mhm38 and its biological applications. J. Nanomater. 2021, 2021, 6693302. [CrossRef]

123. Yusof, H.M.; Mohamad, R.; Zaidan, U.H.; Samsudin, A.A. Biosynthesis of zinc oxide nanoparticles by cell-biomass and supernatant of lactobacillus plantarum ta 4 and its antibacterial and biocompatibility properties. Sci. Rep. 2020, 10, 19996. [CrossRef] [PubMed]

124. Ogunyemi, S.O.; Zhang, M.; Abdallah, Y.; Ahmed, T.; Qiu, W.; Ali, M.; Yan, C.; Yang, Y.; Chen, J.; Li, B. The bio-synthesis of three metal oxide nanoparticles (zno, mno2, and $\mathrm{mgo}$ ) and their antibacterial activity against the bacterial leaf blight pathogen. Front. Microbiol. 2020, 11, 3099. [CrossRef] [PubMed]

125. Irshad, M.A.; Nawaz, R.; ur Rehman, M.Z.; Adrees, M.; Rizwan, M.; Ali, S.; Ahmad, S.; Tasleem, S. Synthesis, characterization and advanced sustainable applications of titanium dioxide nanoparticles: A review. Ecotoxicol. Environ. Saf. 2021, $212,111978$. [CrossRef] [PubMed]

126. Pant, B.; Park, M.; Park, S.-J. Tio2 nps assembled into a carbon nanofiber composite electrode by a one-step electrospinning process for supercapacitor applications. Polymers 2019, 11, 899. [CrossRef] [PubMed]

127. Irshad, M.A.; Nawaz, R.; ur Rehman, M.Z.; Imran, M.; Ahmad, J.; Ahmad, S.; Inam, A.; Razzaq, A.; Rizwan, M.; Ali, S. Synthesis and characterization of titanium dioxide nanoparticles by chemical and green methods and their antifungal activities against wheat rust. Chemosphere 2020, 258, 127352. [CrossRef] 
128. Khan, R.; Fulekar, M. Biosynthesis of titanium dioxide nanoparticles using bacillus amyloliquefaciens culture and enhancement of its photocatalytic activity for the degradation of a sulfonated textile dye reactive red 31. J. Colloid Interface Sci. 2016, 475, 184-191. [CrossRef]

129. Fulekar, J.; Dutta, D.P.; Pathak, B.; Fulekar, M.H. Novel microbial and root mediated green synthesis of tio2 nanoparticles and its application in wastewater remediation. J. Chem. Technol. Biotechnol. 2018, 93, 736-743. [CrossRef]

130. Taran, M.; Rad, M.; Alavi, M. Biosynthesis of tio2 and zno nanoparticles by halomonas elongata ibrc-m 10214 in different conditions of medium. BioImpacts 2018, 8, 81. [CrossRef]

131. Ağçeli, G.K.; Hammachi, H.; Kodal, S.P.; Cihangir, N.; Aksu, Z. A novel approach to synthesize tio 2 nanoparticles: Biosynthesis by using streptomyces sp. Hc1. J. Inorg. Organomet. Polym. Mater. 2020, 30, 3221-3229. [CrossRef]

132. Sundaram, P.A.; Augustine, R.; Kannan, M. Extracellular biosynthesis of iron oxide nanoparticles by bacillus subtilis strains isolated from rhizosphere soil. Biotechnol. Bioprocess Eng. 2012, 17, 835-840. [CrossRef]

133. Majeed, S.; Danish, M.; Ibrahim, M.N.M.; Sekeri, S.H.; Ansari, M.T.; Nanda, A.; Ahmad, G. Bacteria Mediated Synthesis of Iron Oxide Nanoparticles and Their Antibacterial, Antioxidant, Cytocompatibility Properties. J. Clust. Sci. 2020, 1-12. [CrossRef]

134. Gahlawat, G.; Shikha, S.; Chaddha, B.S.; Chaudhuri, S.R.; Mayilraj, S.; Choudhury, A.R. Microbial glycolipoprotein-capped silver nanoparticles as emerging antibacterial agents against cholera. Microb. Cell Fact. 2016, 15, 25. [CrossRef]

135. Mehta, A.; Sidhu, C.; Pinnaka, A.K.; Choudhury, A.R. Extracellular polysaccharide production by a novel osmotolerant marine strain of alteromonas macleodii and its application towards biomineralization of silver. PLoS ONE 2014, 9, e98798. [CrossRef]

136. Raj, R.; Dalei, K.; Chakraborty, J.; Das, S. Extracellular polymeric substances of a marine bacterium mediated synthesis of cds nanoparticles for removal of cadmium from aqueous solution. J. Colloid Interface Sci. 2016, 462, 166-175. [CrossRef]

137. Saxena, I.M.; Dandekar, T.; Brown, R. Mechanisms in cellulose biosynthesis. Mol. Biol. 2004. Available online: http://www.esf. edu/outreach/pd/2000/cellulose/saxena.pdf (accessed on 13 June 2021).

138. Pourreza, N.; Golmohammadi, H.; Naghdi, T.; Yousefi, H. Green in-situ synthesized silver nanoparticles embedded in bacterial cellulose nanopaper as a bionanocomposite plasmonic sensor. Biosens. Bioelectron. 2015, 74, 353-359. [CrossRef]

139. Morales-Narváez, E.; Golmohammadi, H.; Naghdi, T.; Yousefi, H.; Kostiv, U.; Horak, D.; Pourreza, N.; Merkoçi, A. Nanopaper as an optical sensing platform. ACS Nano 2015, 9, 7296-7305. [CrossRef]

140. Ortega, F.G.; Fernández-Baldo, M.A.; Fernández, J.G.; Serrano, M.J.; Sanz, M.I.; Díaz-Mochón, J.J.; Lorente, J.A.; Raba, J. Study of antitumor activity in breast cell lines using silver nanoparticles produced by yeast. Int. J. Nanomed. 2015, 10, 2021.

141. Karthik, L.; Kumar, G.; Kirthi, A.V.; Rahuman, A.A.; Bhaskara Rao, K.V. Streptomyces sp. Lk3 mediated synthesis of silver nanoparticles and its biomedical application. Bioprocess Biosyst. Eng. 2014, 37, 261-267. [CrossRef]

142. Abd-Elnaby, H.M.; Abo-Elala, G.M.; Abdel-Raouf, U.M.; Hamed, M.M. Antibacterial and anticancer activity of extracellular synthesized silver nanoparticles from marine streptomyces rochei mhm13. Egypt. J. Aquat. Res. 2016, 42, 301-312. [CrossRef]

143. Wypij, M.; Czarnecka, J.; Świecimska, M.; Dahm, H.; Rai, M.; Golinska, P. Synthesis, characterization and evaluation of antimicrobial and cytotoxic activities of biogenic silver nanoparticles synthesized from streptomyces xinghaiensis of1 strain. World J. Microbiol. Biotechnol. 2018, 34, 23. [CrossRef]

144. Bakhtiari-Sardari, A.; Mashreghi, M.; Eshghi, H.; Behnam-Rasouli, F.; Lashani, E.; Shahnavaz, B. Comparative evaluation of silver nanoparticles biosynthesis by two cold-tolerant streptomyces strains and their biological activities. Biotechnol. Lett. 2020, 42, 1985-1999. [CrossRef]

145. Ahmad, A.; Senapati, S.; Khan, M.I.; Kumar, R.; Sastry, M. Extracellular biosynthesis of monodisperse gold nanoparticles by a novel extremophilic actinomycete, thermomonospora sp. Langmuir 2003, 19, 3550-3553. [CrossRef]

146. Ahmad, A.; Senapati, S.; Khan, M.I.; Kumar, R.; Ramani, R.; Srinivas, V.; Sastry, M. Intracellular synthesis of gold nanoparticles by a novel alkalotolerant actinomycete, rhodococcus species. Nanotechnology 2003, 14, 824. [CrossRef]

147. He, S.; Guo, Z.; Zhang, Y.; Zhang, S.; Wang, J.; Gu, N. Biosynthesis of gold nanoparticles using the bacteria rhodopseudomonas capsulata. Mater. Lett. 2007, 61, 3984-3987. [CrossRef]

148. Ranjitha, V.R.; Rai, V.R. Actinomycetes mediated synthesis of gold nanoparticles from the culture supernatant of streptomyces griseoruber with special reference to catalytic activity. 3 Biotech 2017, 7, 299. [CrossRef] [PubMed]

149. Hassan, S.E.L.D.; Salem, S.S.; Fouda, A.; Awad, M.A.; El-Gamal, M.S.; Abdo, A.M. New approach for antimicrobial activity and bio-control of various pathogens by biosynthesized copper nanoparticles using endophytic actinomycetes. J. Radiat. Res. Appl. Sci. 2018, 11, 262-270. [CrossRef]

150. Mishra, A.; Kumari, M.; Pandey, S.; Chaudhry, V.; Gupta, K.; Nautiyal, C. Biocatalytic and antimicrobial activities of gold nanoparticles synthesized by trichoderma sp. Bioresour. Technol. 2014, 166, 235-242. [CrossRef] [PubMed]

151. Metuku, R.P.; Pabba, S.; Burra, S.; Gudikandula, K.; Charya, M.S. Biosynthesis of silver nanoparticles from schizophyllum radiatum he 863742.1: Their characterization and antimicrobial activity. 3 Biotech 2014, 4, 227-234. [CrossRef]

152. Bhargava, A.; Jain, N.; Khan, M.A.; Pareek, V.; Dilip, R.V.; Panwar, J. Utilizing metal tolerance potential of soil fungus for efficient synthesis of gold nanoparticles with superior catalytic activity for degradation of rhodamine b. J. Environ. Manag. 2016, 183, 22-32. [CrossRef]

153. Rajput, S.; Werezuk, R.; Lange, R.M.; McDermott, M.T. Fungal isolate optimized for biogenesis of silver nanoparticles with enhanced colloidal stability. Langmuir 2016, 32, 8688-8697. [CrossRef]

154. Gericke, M.; Pinches, A. Microbial production of gold nanoparticles. Gold Bull. 2006, 39, 22-28. [CrossRef] 
155. Birla, S.S.; Gaikwad, S.C.; Gade, A.K.; Rai, M.K. Rapid synthesis of silver nanoparticles from fusarium oxysporum by optimizing physicocultural conditions. Sci. World J. 2013, 2013, 796018. [CrossRef] [PubMed]

156. Kitching, M.; Choudhary, P.; Inguva, S.; Guo, Y.; Ramani, M.; Das, S.K.; Marsili, E. Fungal surface protein mediated one-pot synthesis of stable and hemocompatible gold nanoparticles. Enzym. Microb. Technol. 2016, 95, 76-84. [CrossRef] [PubMed]

157. El Domany, E.B.; Essam, T.M.; Ahmed, A.E.; Farghali, A.A. Biosynthesis physico-chemical optimization of gold nanoparticles as anti-cancer and synergetic antimicrobial activity using pleurotus ostreatus fungus. J. Appl. Pharm. Sci. 2018, 8, 119-128.

158. Neethu, S.; Midhun, S.J.; Sunil, M.; Soumya, S.; Radhakrishnan, E.; Jyothis, M. Efficient visible light induced synthesis of silver nanoparticles by penicillium polonicum ara 10 isolated from chetomorpha antennina and its antibacterial efficacy against salmonella enterica serovar typhimurium. J. Photochem. Photobiol. B Biol. 2018, 180, 175-185. [CrossRef]

159. Clarance, P.; Luvankar, B.; Sales, J.; Khusro, A.; Agastian, P.; Tack, J.C.; Al Khulaifi, M.M.; Al-Shwaiman, H.A.; Elgorban, A.M.; Syed, A.; et al. Green synthesis and characterization of gold nanoparticles using endophytic fungi fusarium solani and its in-vitro anticancer and biomedical applications. Saudi J. Biol. Sci. 2020, 27, 706-712. [CrossRef]

160. Munawer, U.; Raghavendra, V.B.; Ningaraju, S.; Krishna, K.L.; Ghosh, A.R.; Melappa, G.; Pugazhendhi, A. Biofabrication of gold nanoparticles mediated by the endophytic cladosporium species: Photodegradation, in vitro anticancer activity and in vivo antitumor studies. Int. J. Pharm. 2020, 588, 119729. [CrossRef]

161. Ramos, M.M.; Morais, E.d.S.; Sena, I.d.S.; Lima, A.L.; de Oliveira, F.R.; de Freitas, C.M.; Fernandes, C.P.; de Carvalho, J.C.T.; Ferreira, I.M. Silver nanoparticle from whole cells of the fungi trichoderma spp. Isolated from brazilian amazon. Biotechnol. Lett. 2020, 42, 833-843. [CrossRef]

162. Apte, M.; Sambre, D.; Gaikawad, S.; Joshi, S.; Bankar, A.; Kumar, A.R.; Zinjarde, S. Psychrotrophic yeast yarrowia lipolytica ncyc 789 mediates the synthesis of antimicrobial silver nanoparticles via cell-associated melanin. AMB Express 2013, 3, 32. [CrossRef]

163. Zhang, X.; Qu, Y.; Shen, W.; Wang, J.; Li, H.; Zhang, Z.; Li, S.; Zhou, J. Biogenic synthesis of gold nanoparticles by yeast magnusiomyces ingens lh-f1 for catalytic reduction of nitrophenols. Colloids Surf. A Physicochem. Eng. Asp. 2016, 497, 280-285. [CrossRef]

164. Eugenio, M.; Müller, N.; Frasés, S.; Almeida-Paes, R.; Lima, L.M.T.; Lemgruber, L.; Farina, M.; de Souza, W.; Sant'Anna, C. Yeast-derived biosynthesis of silver/silver chloride nanoparticles and their antiproliferative activity against bacteria. RSC Adv. 2016, 6, 9893-9904. [CrossRef]

165. Elahian, F.; Reiisi, S.; Shahidi, A.; Mirzaei, S.A. High-throughput bioaccumulation, biotransformation, and production of silver and selenium nanoparticles using genetically engineered pichia pastoris. Nanomed. Nanotechnol. Biol. Med. 2017, 13, 853-861. [CrossRef]

166. Sriramulu, M.; Sumathi, S. Biosynthesis of palladium nanoparticles using saccharomyces cerevisiae extract and its photocatalytic degradation behaviour. Adv. Nat. Sci. Nanosci. Nanotechnol. 2018, 9, 025018. [CrossRef]

167. Ansari, M.A.; Khan, H.M.; Khan, A.A.; Pal, R.; Cameotra, S.S. Antibacterial potential of al 2 o 3 nanoparticles against multidrug resistance strains of staphylococcus aureus isolated from skin exudates. J. Nanopart. Res. 2013, 15, 1970. [CrossRef]

168. Suryavanshi, P.; Pandit, R.; Gade, A.; Derita, M.; Zachino, S.; Rai, M. Colletotrichum sp.-mediated synthesis of sulphur and aluminium oxide nanoparticles and its in vitro activity against selected food-borne pathogens. Lebenson Wiss. Technol. 2017, 81, 188-194. [CrossRef]

169. Fouda, A.; Saad, E.; Salem, S.S.; Shaheen, T.I. In-vitro cytotoxicity, antibacterial, and uv protection properties of the biosynthesized zinc oxide nanoparticles for medical textile applications. Microb. Pathog. 2018, 125, 252-261. [CrossRef]

170. Mohamed, A.A.; Fouda, A.; Abdel-Rahman, M.A.; Hassan, S.E.-D.; El-Gamal, M.S.; Salem, S.S.; Shaheen, T.I. Fungal strain impacts the shape, bioactivity and multifunctional properties of green synthesized zinc oxide nanoparticles. Biocatal. Agric. Biotechnol. 2019, 19, 101103. [CrossRef]

171. Sumanth, B.; Lakshmeesha, T.R.; Ansari, M.A.; Alzohairy, M.A.; Udayashankar, A.C.; Shobha, B.; Niranjana, S.R.; Srinivas, C.; Almatroudi, A. Mycogenic synthesis of extracellular zinc oxide nanoparticles from xylaria acuta and its nanoantibiotic potential. Int. J. Nanomed. 2020, 15, 8519. [CrossRef]

172. Ashajyothi, C.; Harish, K.H.; Dubey, N.; Chandrakanth, R.K. Antibiofilm activity of biogenic copper and zinc oxide nanoparticlesantimicrobials collegiate against multiple drug resistant bacteria: A nanoscale approach. J. Nanostruct. Chem. 2016, 6, 329-341. [CrossRef]

173. Mohamed, A.A.; Abu-Elghait, M.; Ahmed, N.E.; Salem, S.S. Eco-friendly mycogenic synthesis of zno and cuo nanoparticles for in vitro antibacterial, antibiofilm, and antifungal applications. Biol. Trace Elem. Res. 2020, 1-12. [CrossRef]

174. Badawy, A.A.; Abdelfattah, N.A.; Salem, S.S.; Awad, M.F.; Fouda, A. Efficacy assessment of biosynthesized copper oxide nanoparticles (cuo-nps) on stored grain insects and their impacts on morphological and physiological traits of wheat (triticum aestivum 1.) plant. Biology 2021, 10, 233. [CrossRef]

175. Fouda, A.; Salem, S.S.; Wassel, A.R.; Hamza, M.F.; Shaheen, T.I. Optimization of green biosynthesized visible light active cuo/zno nano-photocatalysts for the degradation of organic methylene blue dye. Heliyon 2020, 6, e04896. [CrossRef]

176. Peiris, M.; Guansekera, T.; Jayaweera, P.; Fernando, S. Tio 2 nanoparticles from baker's yeast: A potent antimicrobial. J. Microbiol. Biotechnol. 2018, 28, 1664-1670. [CrossRef]

177. Chinnaperumal, K.; Govindasamy, B.; Paramasivam, D.; Dilipkumar, A.; Dhayalan, A.; Vadivel, A.; Sengodan, K.; Pachiappan, P. Bio-pesticidal effects of trichoderma viride formulated titanium dioxide nanoparticle and their physiological and biochemical changes on helicoverpa armigera (hub.). Pestic Biochem. Physiol. 2018, 149, 26-36. [CrossRef] 
178. Manimaran, K.; Murugesan, S.; Ragavendran, C.; Balasubramani, G.; Natarajan, D.; Ganesan, A.; Seedevi, P. Biosynthesis of tio 2 nanoparticles using edible mushroom (pleurotus djamor) extract: Mosquito larvicidal, histopathological, antibacterial and anticancer effect. J. Clust. Sci. 2020, 1-12. [CrossRef]

179. Ali, A.; Hira Zafar, M.Z.; ul Haq, I.; Phull, A.R.; Ali, J.S.; Hussain, A. Synthesis, characterization, applications, and challenges of iron oxide nanoparticles. Nanotechnol. Sci. Appl. 2016, 9, 49. [CrossRef]

180. Bhargava, A.; Jain, N.; Barathi, M.; Akhtar, M.S.; Yun, Y.-S.; Panwar, J. Synthesis, Characterization and Mechanistic Insights of Mycogenic Iron Oxide Nanoparticles. J. Nanopart. Res. 2013, 15, 2031. [CrossRef]

181. Mahanty, S.; Bakshi, M.; Ghosh, S.; Chatterjee, S.; Bhattacharyya, S.; Das, P.; Das, S.; Chaudhuri, P. Green synthesis of iron oxide nanoparticles mediated by filamentous fungi isolated from sundarban mangrove ecosystem, india. Bionanoscience 2019, 9, 637-651. [CrossRef]

182. Mahanty, S.; Bakshi, M.; Ghosh, S.; Gaine, T.; Chatterjee, S.; Bhattacharyya, S.; Das, S.; Das, P.; Chaudhuri, P. Mycosynthesis of iron oxide nanoparticles using manglicolous fungi isolated from indian sundarbans and its application for the treatment of chromium containing solution: Synthesis, adsorption isotherm, kinetics and thermodynamics study. Environ. Nanotechnol. Monit. Manag. 2019, 12, 100276. [CrossRef]

183. Vijayanandan, A.S.; Balakrishnan, R.M. Biosynthesis of cobalt oxide nanoparticles using endophytic fungus aspergillus nidulans. J. Environ. Manag. 2018, 218, 442-450. [CrossRef]

184. Fawcett, D.; Verduin, J.J.; Shah, M.; Sharma, S.B.; Poinern, G.E.J. A review of current research into the biogenic synthesis of metal and metal oxide nanoparticles via marine algae and seagrasses. J. Nanosci. 2017, 2017, 8013850. [CrossRef]

185. Dhas, T.S.; Kumar, V.G.; Karthick, V.; Angel, K.J.; Govindaraju, K. Facile synthesis of silver chloride nanoparticles using marine alga and its antibacterial efficacy. Spectrochim. Acta Part A Mol. Biomol. Spectrosc. 2014, 120, 416-420. [CrossRef] [PubMed]

186. Edison, T.N.J.I.; Atchudan, R.; Kamal, C.; Lee, Y.R. Caulerpa racemosa: A marine green alga for eco-friendly synthesis of silver nanoparticles and its catalytic degradation of methylene blue. Bioprocess Biosyst. Eng. 2016, 39, 1401-1408. [CrossRef] [PubMed]

187. da Silva Ferreira, V.; ConzFerreira, M.E.; Lima, L.M.T.R.; Frasés, S.; de Souza, W.; Sant'Anna, C. Green production of microalgaebased silver chloride nanoparticles with antimicrobial activity against pathogenic bacteria. Enzym. Microb. Technol. 2017, 97, 114-121. [CrossRef]

188. Kim, D.-Y.; Saratale, R.G.; Shinde, S.; Syed, A.; Ameen, F.; Ghodake, G. Green synthesis of silver nanoparticles using laminaria japonica extract: Characterization and seedling growth assessment. J. Clean. Prod. 2018, 172, 2910-2918. [CrossRef]

189. Fatima, R.; Priya, M.; Indurthi, L.; Radhakrishnan, V.; Sudhakaran, R. Biosynthesis of silver nanoparticles using red algae portieria hornemannii and its antibacterial activity against fish pathogens. Microb. Pathog. 2020, 138, 103780. [CrossRef]

190. Bhuyar, P.; Rahim, M.H.A.; Sundararaju, S.; Ramaraj, R.; Maniam, G.P.; Govindan, N. Synthesis of silver nanoparticles using marine macroalgae padina sp. And its antibacterial activity towards pathogenic bacteria. Beni-Suef Univ. J. Basic Appl. Sci. 2020, 9 , 3. [CrossRef]

191. Senapati, S.; Syed, A.; Moeez, S.; Kumar, A.; Ahmad, A. Intracellular synthesis of gold nanoparticles using alga tetraselmis kochinensis. Mater. Lett. 2012, 79, 116-118. [CrossRef]

192. Singh, M.; Kalaivani, R.; Manikandan, S.; Sangeetha, N.; Kumaraguru, A.K. Facile green synthesis of variable metallic gold nanoparticle using padina gymnospora, a brown marine macroalga. Appl. Nanosci. 2013, 3, 145-151. [CrossRef]

193. Dahoumane, S.A.; Yéprémian, C.; Djédiat, C.; Couté, A.; Fiévet, F.; Coradin, T.; Brayner, R. Improvement of kinetics, yield, and colloidal stability of biogenic gold nanoparticles using living cells of euglena gracilis microalga. J. Nanopart. Res. 2016, 18, 79. [CrossRef]

194. Ramakrishna, M.; Rajesh Babu, D.; Gengan, R.M.; Chandra, S.; Nageswara Rao, G. Green synthesis of gold nanoparticles using marine algae and evaluation of their catalytic activity. J. Nanostruct. Chem. 2016, 6, 1-13. [CrossRef]

195. González-Ballesteros, N.; Prado-López, S.; Rodríguez-González, J.B.; Lastra, M.; Rodríguez-Argüelles, M.C. Green synthesis of gold nanoparticles using brown algae cystoseira baccata: Its activity in colon cancer cells. Colloids Surf. B Biointerfaces 2017, 153, 190-198. [CrossRef]

196. Momeni, S.; Nabipour, I. A simple green synthesis of palladium nanoparticles with sargassum alga and their electrocatalytic activities towards hydrogen peroxide. Appl. Biochem. Biotechnol. 2015, 176, 1937-1949. [CrossRef]

197. Arsiya, F.; Sayadi, M.H.; Sobhani, S. Green synthesis of palladium nanoparticles using chlorella vulgaris. Mater. Lett. 2017, 186, 113-115. [CrossRef]

198. Sayadi, M.H.; Salmani, N.; Heidari, A.; Rezaei, M.R. Bio-synthesis of palladium nanoparticle using spirulina platensis alga extract and its application as adsorbent. Surf. Interfaces 2018, 10, 136-143. [CrossRef]

199. Rajeshkumar, S.; Kannan, C.; Annadurai, G. Green synthesis of silver nanoparticles using marine brown algae turbinaria conoides and its antibacterial activity. Int. J. Pharma Bio Sci. 2012, 3, 502-510.

200. Khalafi, T.; Buazar, F.; Ghanemi, K. Phycosynthesis and enhanced photocatalytic activity of zinc oxide nanoparticles toward organosulfur pollutants. Sci. Rep. 2019, 9, 6866. [CrossRef]

201. Taghizadeh, S.-M.; Lal, N.; Ebrahiminezhad, A.; Moeini, F.; Seifan, M.; Ghasemi, Y.; Berenjian, A. Green and economic fabrication of zinc oxide (zno) nanorods as a broadband uv blocker and antimicrobial agent. Nanomaterials 2020, 10, 530. [CrossRef]

202. El-Belely, E.F.; Farag, M.; Said, H.A.; Amin, A.S.; Azab, E.; Gobouri, A.A.; Fouda, A. Green synthesis of zinc oxide nanoparticles (zno-nps) using arthrospira platensis (class: Cyanophyceae) and evaluation of their biomedical activities. Nanomaterials 2021, 11, 95. [CrossRef] 


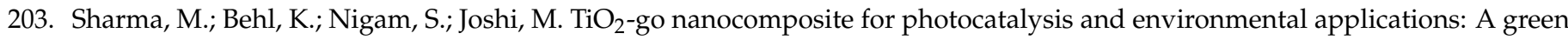
synthesis approach. Vacuum 2018, 156, 434-439. [CrossRef]

204. El-Kassas, H.Y.; Aly-Eldeen, M.A.; Gharib, S.M. Green synthesis of iron oxide $\left(\mathrm{Fe}_{3} \mathrm{O}_{4}\right)$ nanoparticles using two selected brown seaweeds: Characterization and application for lead bioremediation. Acta Oceanol. Sin. 2016, 35, 89-98. [CrossRef]

205. Kobayashi, M.; Tomita, S.; Sawada, K.; Shiba, K.; Yanagi, H.; Yamashita, I.; Uraoka, Y. Chiral meta-molecules consisting of gold nanoparticles and genetically engineered tobacco mosaic virus. Opt. Express 2012, 20, 24856-24863. [CrossRef]

206. Mao, C.; Flynn, C.E.; Hayhurst, A.; Sweeney, R.; Qi, J.; Georgiou, G.; Iverson, B.; Belcher, A.M. Viral assembly of oriented quantum dot nanowires. Proc. Natl. Acad. Sci. USA 2003, 100, 6946-6951. [CrossRef] [PubMed]

207. Slocik, J.M.; Naik, R.R.; Stone, M.O.; Wright, D.W. Viral templates for gold nanoparticle synthesis. J. Mater. Chem. 2005, 15, 749-753. [CrossRef]

208. Cao, J.; Guenther, R.H.; Sit, T.L.; Opperman, C.H.; Lommel, S.A.; Willoughby, J.A. Loading and release mechanism of red clover necrotic mosaic virus derived plant viral nanoparticles for drug delivery of doxorubicin. Small 2014, 10, 5126-5136. [CrossRef]

209. Czapar, A.E.; Zheng, Y.R.; Riddell, I.A.; Shukla, S.; Awuah, S.G.; Lippard, S.J.; Steinmetz, N.F. Tobacco mosaic virus delivery of phenanthriplatin for cancer therapy. ACS Nano 2016, 10, 4119-4126. [CrossRef] [PubMed]

210. Le, D.H.T.; Lee, K.L.; Shukla, S.; Commandeur, U.; Steinmetz, N.F. Potato virus x, a filamentous plant viral nanoparticle for doxorubicin delivery in cancer therapy. Nanoscale 2017, 9, 2348-2357. [CrossRef]

211. Chen, C.C.; Stark, M.; Baikoghli, M.; Cheng, R.H. Surface functionalization of hepatitis e virus nanoparticles using chemical conjugation methods. J. Vis. Exp. 2018, 57020. [CrossRef]

212. Thangavelu, R.M.; Ganapathy, R.; Ramasamy, P.; Krishnan, K. Fabrication of virus metal hybrid nanomaterials: An ideal reference for bio semiconductor. Arab. J. Chem. 2020, 13, 2750-2765. [CrossRef]

213. Mandeep, P.S. Microbial nanotechnology for bioremediation of industrial wastewater. Front. Microbiol. 2020, $11,590631$. [CrossRef]

214. Seil, J.T.; Webster, T.J. Antimicrobial applications of nanotechnology: Methods and literature. Int. J. Nanomed. $2012,7,2767$.

215. Sondi, I.; Salopek-Sondi, B. Silver nanoparticles as antimicrobial agent: A case study on e. Coli as a model for gram-negative bacteria. J. Colloid Interface Sci. 2004, 275, 177-182. [CrossRef]

216. Banu, A.; Rathod, V.; Ranganath, E. Silver nanoparticle production by rhizopus stolonifer and its antibacterial activity against extended spectrum $\beta$-lactamase producing (esbl) strains of enterobacteriaceae. Mater. Res. Bull. 2011, 46, 1417-1423. [CrossRef]

217. Singh, P.; Kim, Y.J.; Singh, H.; Wang, C.; Hwang, K.H.; Farh Mel, A.; Yang, D.C. Biosynthesis, characterization, and antimicrobial applications of silver nanoparticles. Int. J. Nanomed. 2015, 10, 2567-2577. [CrossRef]

218. Elbeshehy, E.K.; Elazzazy, A.M.; Aggelis, G. Silver nanoparticles synthesis mediated by new isolates of bacillus spp., nanoparticle characterization and their activity against bean yellow mosaic virus and human pathogens. Front. Microbiol. $2015,6,453$. [CrossRef]

219. Mahmoud, W.M.; Abdelmoneim, T.S.; Elazzazy, A.M. The impact of silver nanoparticles produced by bacillus pumilus as antimicrobial and nematicide. Front. Microbiol. 2016, 7, 1746. [CrossRef]

220. Malarkodi, C.; Chitra, K.; Rajeshkumar, S.; Gnanajobitha, G.; Paulkumar, K.; Vanaja, M.; Annadurai, G. Novel eco-friendly synthesis of titanium oxide nanoparticles by using planomicrobium sp. And its antimicrobial evaluation. Der Pharm. Sin. 2013, 4, 59-66.

221. Raghupathi, K.R.; Koodali, R.T.; Manna, A.C. Size-dependent bacterial growth inhibition and mechanism of antibacterial activity of zinc oxide nanoparticles. Langmuir 2011, 27, 4020-4028. [CrossRef]

222. Ibrahim, N.A.; Nada, A.A.; Hassabo, A.G.; Eid, B.M.; El-Deen, A.M.N.; Abou-Zeid, N.Y. Effect of different capping agents on physicochemical and antimicrobial properties of zno nanoparticles. Chem. Pap. 2017, 71, 1365-1375. [CrossRef]

223. Mohammadi, F.M.; Ghasemi, N. Influence of temperature and concentration on biosynthesis and characterization of zinc oxide nanoparticles using cherry extract. J. Nanostruct. Chem. 2018, 8, 93-102. [CrossRef]

224. Jain, D.; Shivani, A.A.B.; Singh, H.; Daima, H.K.; Singh, M.; Mohanty, S.R.; Stephen, B.J.; Singh, A. Microbial fabrication of zinc oxide nanoparticles and evaluation of their antimicrobial and photocatalytic properties. Front. Chem. 2020, 8, 778. [CrossRef]

225. Jabir, N.R.; Tabrez, S.; Ashraf, G.M.; Shakil, S.; Damanhouri, G.A.; Kamal, M.A. Nanotechnology-based approaches in anticancer research. Int. J. Nanomed. 2012, 7, 4391-4408. [CrossRef]

226. Sutradhar, K.B.; Amin, M. Nanotechnology in cancer drug delivery and selective targeting. Int. Sch. Res. Notices 2014, 2014, 939378. [CrossRef]

227. Borse, V.; Kaler, A.; Banerjee, U.C. Microbial synthesis of platinum nanoparticles and evaluation of their anticancer activity. Int. J. Emerg. Trends Electr. Electron 2015, 11, 2320-9569.

228. El-Batal, A.; Al Tamie, M. Biosynthesis of gold nanoparticles using marine streptomyces cyaneus and their antimicrobial, antioxidant and antitumor (in vitro) activities. J. Chem. Pharm. Res. 2015, 7, 1020-1036.

229. Salouti, M.; Ahangari, A. Nanoparticle Based Drug Delivery Systems for Treatment of Infectious Diseases. In Application of Nanotechnology in Drug Delivery; InTech: London, UK, 2014; pp. 155-192. [CrossRef]

230. Omlor, A.J.; Nguyen, J.; Bals, R.; Dinh, Q.T. Nanotechnology in respiratory medicine. Respir. Res. 2015, 16, 64. [CrossRef]

231. Kundu, D.; Hazra, C.; Chatterjee, A.; Chaudhari, A.; Mishra, S. Extracellular biosynthesis of zinc oxide nanoparticles using rhodococcus pyridinivorans nt2: Multifunctional textile finishing, biosafety evaluation and in vitro drug delivery in colon carcinoma. J. Photochem. Photobiol. B Biol. 2014, 140, 194-204. [CrossRef] 
232. Kumar, S.A.; Peter, Y.-A.; Nadeau, J.L. Facile biosynthesis, separation and conjugation of gold nanoparticles to doxorubicin. Nanotechnology 2008, 19, 495101. [CrossRef]

233. Khan, S.A.; Gambhir, S.; Ahmad, A. Extracellular biosynthesis of gadolinium oxide (gd2o3) nanoparticles, their biodistribution and bioconjugation with the chemically modified anticancer drug taxol. Beilstein J. Nanotechnol. 2014, 5, 249-257. [CrossRef] [PubMed]

234. Tallury, P.; Malhotra, A.; Byrne, L.M.; Santra, S. Nanobioimaging and sensing of infectious diseases. Adv. Drug Deliv. Rev. 2010, 62, 424-437. [CrossRef] [PubMed]

235. Chauhan, A.; Zubair, S.; Tufail, S.; Sherwani, A.; Sajid, M.; Raman, S.C.; Azam, A.; Owais, M. Fungus-mediated biological synthesis of gold nanoparticles: Potential in detection of liver cancer. Int. J. Nanomed. 2011, 6, 2305-2319. [CrossRef]

236. Shukla, K. Nanotechnology and emerging trends in dairy foods: The inside story to food additives and ingredients. Int. J. Nanosci. Nanotechnol. 2012, 1, 41-58.

237. Espitia, P.J.P.; Soares, N.d.F.F.; dos Reis Coimbra, J.S.; de Andrade, N.J.; Cruz, R.S.; Medeiros, E.A.A. Zinc oxide nanoparticles: Synthesis, antimicrobial activity and food packaging applications. Food Bioproc. Tech. 2012, 5, 1447-1464. [CrossRef]

238. Rajamanickam, U.; Mylsamy, P.; Viswanathan, S.; Muthusamy, P. Biosynthesis of Zinc Nanoparticles Using Actinomycetes for Antibacterial Food Packaging. In Proceedings of the International Conference on nutrition and food sciences IPCBEE, Singapore, 23-24 July 2012.

239. Prasad, R.; Kumar, V.; Prasad, K.S. Nanotechnology in sustainable agriculture: Present concerns and future aspects. Afr. J. Biotechnol. 2014, 13, 705-713.

240. Huang, J.; Lin, L.; Sun, D.; Chen, H.; Yang, D.; Li, Q. Bio-inspired synthesis of metal nanomaterials and applications. Chem. Soc. Rev. 2015, 44, 6330-6374. [CrossRef]

241. Kaur, P.; Thakur, R.; Duhan, J.S.; Chaudhury, A. Management of wilt disease of chickpea in vivo by silver nanoparticles biosynthesized by rhizospheric microflora of chickpea (cicer arietinum). J. Chem. Technol. Biotechnol. 2018, 93, 3233-3243. [CrossRef]

242. Bisinoti, M.C.; Moreira, A.B.; Melo, C.A.; Fregolente, L.G.; Bento, L.R.; dos Santos, J.V.; Ferreira, O.P. Application of Carbon-Based Nanomaterials as Fertilizers in Soils. In Nanomaterials Applications for Environmental Matrices: Water, Soil and Air; do Nascimento, R.F., Nascimento, R.F., Ferreira, O.P., Paula, A.J., Neto, V.O.S., Eds.; Elsevier: Amsterdam, The Netherlands, 2019 ; pp. 305-333. [CrossRef]

243. Guo, H.; White, J.C.; Wang, Z.; Xing, B. Nano-enabled fertilizers to control the release and use efficiency of nutrients. Curr. Opin. Environ. Sci. Health 2018, 6, 77-83. [CrossRef]

244. Subbarao, C.V.; Kartheek, G.; Sirisha, D. Slow release of potash fertilizer through polymer coating. Int. J. Appl. Sci. Eng. 2013, 11, 25-30.

245. Duhan, J.S.; Kumar, R.; Kumar, N.; Kaur, P.; Nehra, K.; Duhan, S. Nanotechnology: The new perspective in precision agriculture. Biotechnol. Rep. 2017, 15, 11-23. [CrossRef]

246. Rai, M.; Ingle, A. Role of nanotechnology in agriculture with special reference to management of insect pests. Appl. Microbiol. Biotechnol. 2012, 94, 287-293. [CrossRef]

247. Goswami, A.; Roy, I.; Sengupta, S.; Debnath, N. Novel applications of solid and liquid formulations of nanoparticles against insect pests and pathogens. Thin Solid Films 2010, 519, 1252-1257. [CrossRef]

248. Athanassiou, C.; Kavallieratos, N.; Benelli, G.; Losic, D.; Rani, P.U.; Desneux, N. Nanoparticles for pest control: Current status and future perspectives. J. Pest Sci. 2018, 91, 1-15. [CrossRef]

249. Rawtani, D.; Khatri, N.; Tyagi, S.; Pandey, G. Nanotechnology-based recent approaches for sensing and remediation of pesticides. J. Environ. Manag. 2018, 206, 749-762. [CrossRef]

250. Wang, L.; Li, X.; Zhang, G.; Dong, J.; Eastoe, J. Oil-in-water nanoemulsions for pesticide formulations. J. Colloid Interface Sci. 2007, 314, 230-235. [CrossRef]

251. Zhao, J.; Wu, T.; Wu, K.; Oikawa, K.; Hidaka, H.; Serpone, N. Photoassisted degradation of dye pollutants. 3. Degradation of the cationic dye rhodamine $\mathrm{b}$ in aqueous anionic surfactant/tio2 dispersions under visible light irradiation: Evidence for the need of substrate adsorption on tio2 particles. Environ. Sci. Technol. 1998, 32, 2394-2400. [CrossRef]

252. Kharissova, O.V.; Dias, H.R.; Kharisov, B.I.; Pérez, B.O.; Pérez, V.M.J. The greener synthesis of nanoparticles. Trends Biotechnol. 2013, 31, 240-248. [CrossRef]

253. Sharma, K.; Singh, G.; Kumar, M.; Bhalla, V. Silver nanoparticles: Facile synthesis and their catalytic application for the degradation of dyes. RSC Adv. 2015, 5, 25781-25788. [CrossRef]

254. Suvith, V.; Philip, D. Catalytic degradation of methylene blue using biosynthesized gold and silver nanoparticles. Spectrochim. Acta Part A Mol. Biomol. Spectrosc. 2014, 118, 526-532. [CrossRef]

255. Panáček, A.; Prucek, R.; Hrbáč, J.; Nevečná, T.; Šteffková, J.; Zbořil, R.; Kvítek, L. Polyacrylate-Assisted Size Control of Silver Nanoparticles and Their Catalytic Activity. Chem. Mater. 2014, 26, 1332-1339. [CrossRef]

256. Koul, B.; Taak, P. (Eds.) Biotechnological Strategies for Effective Remediation of Polluted Soils; Springer: Singapore, 2018 ; pp. 77-84.

257. Hamida, R.S.; Albasher, G.; Bin-Meferij, M.M. Oxidative stress and apoptotic responses elicited by nostoc-synthesized silver nanoparticles against different cancer cell lines. Cancers 2020, 12, 2099. [CrossRef] 
258. Hamida, R.S.; Ali, M.A.; Goda, D.A.; Khalil, M.I.; Al-Zaban, M.I. Novel biogenic silver nanoparticle-induced reactive oxygen species inhibit the biofilm formation and virulence activities of methicillin-resistant staphylococcus aureus (mrsa) strain. Front. Bioeng. Biotechnol. 2020, 8, 433. [CrossRef]

259. Hamida, R.S.; Ali, M.A.; Redhwan, A.; Bin-Meferij, M.M. Cyanobacteria-a promising platform in green nanotechnology: A review on nanoparticles fabrication and their prospective applications. Int. J. Nanomed. 2020, 15, 6033. [CrossRef]

260. Xu, L.; Wang, Y.-Y.; Huang, J.; Chen, C.-Y.; Wang, Z.-X.; Xie, H. Silver nanoparticles: Synthesis, medical applications and biosafety. Theranostics 2020, 10, 8996. [CrossRef] 